Repair, Evaluation, Maintenance, and Rehabilitation Research Program

\title{
Toe Stability of Rubble-Mound Structures in a Breaking Wave and Ebb Flow Environment
}

by Ernest R. Smith 
The following two letters used as part of the number designating technical reports of research published under the Repair. Evaluation, Maintenance, and Rehabilitation (REMR) Research Program identify the problem area under which the report was prepared:

Problem Area

CS

GI

HY

$\mathrm{CO}$
Concrete and Steel Structures

Geotechnical

Hydraulics

Coastal
Problem Area

EM

EI

OM
Electrical and Mechanical

Environmental Impacts

Operations Management

The contents of this report are not to be used for advertising, publication, or promotional purposes. Citation of trade names does not constitute an official endorsement or approval of the use of such commercial products.

The findings of this report are not to be construed as an ofticial Department of the Army position, unless so designated by other authorized documents. 


\section{Toe Stability of Rubble-Mound Structures in a Breaking Wave and Ebb Flow Environment}

by Ernest R. Smith

U.S. Army Corps of Engineers Waterways Experiment Station 3909 Halls Ferry Road

Vicksburg, MS 39180-6199

Final report

Approved for public release; distribution is unlimited

Prepared for U.S. Army Corps of Engineers

Washington, DC 20314-1000

Under Work Unit 32660 


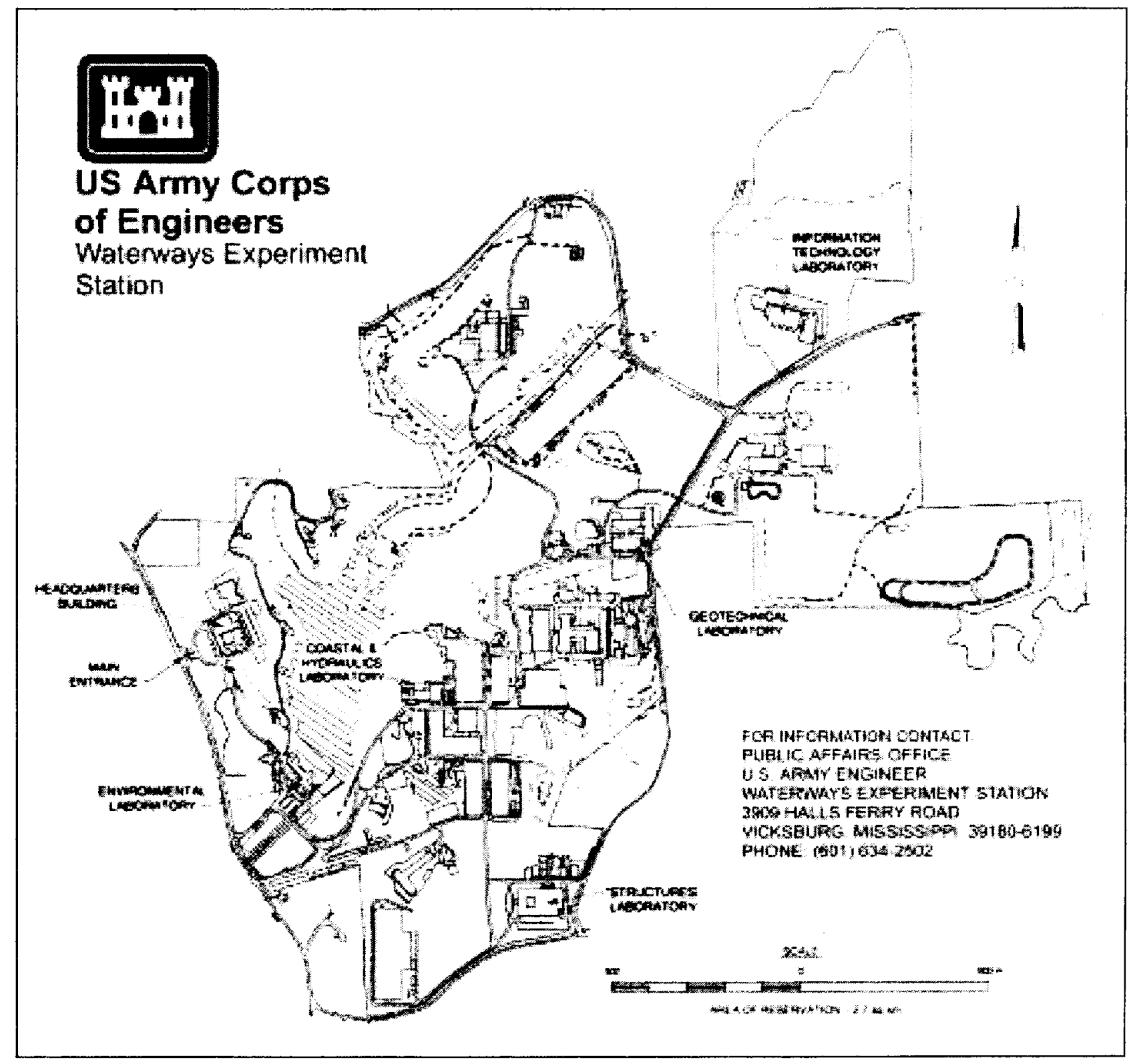

\section{Waterways Experiment Station Cataloging-in-Publication Data}

Smith, Ernest R

Toe stability of rubble-mound structures in a breaking wave and ebb flow environment / by Ernest R. Smith ; prepared for U.S. Army Corps of Engineers.

41 p. : ill. ; $28 \mathrm{~cm}$. - (Technical report ; REMR-CO-20)

Includes bibliographic references.

1. Rubble mound breakwaters - Mathematical models. 2. Breakwaters - Mathematical models. I. United States. Army. Corps of Engineers. II. U.S. Army Engineer Waterways Experiment Station. III. Repair, Evaluation, Maintenance and Rehabilitation Research Program. IV. Title. V. Series: Technical report (U.S. Army Engineer Waterways Experiment Station) ; REMR-CO-20.

TA7 W34 no.REMR-CO-20 


\section{Contents}

Preface ..................... v

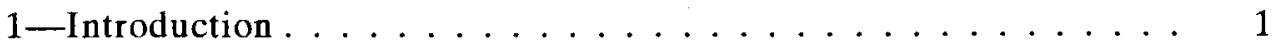

Background . . . . . . . . . . . . . . . 1

Study Purpose ........................ 3

2-The Model .................... 5

Design of Model . . . . . . . . . . . . . . . 5

Model Experiments .................... 5

Facilities and equiment ................. 5

Procedures .................. 7

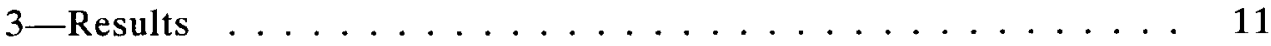

Fixed-Bed Experiments . . . . . . . . . . . . . . 11

Qualitative results . . . . . . . . . . . . . 11

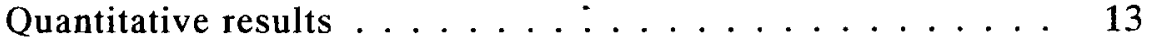

Movable-Bed Experiments . . . . . . . . . . . . . . . 19

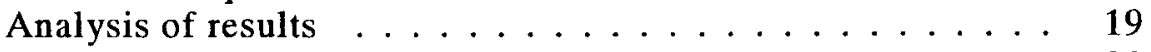

Bendway weir study results . . . . . . . . . . 23

$4-$ Summary and Conclusions . . . . . . . . . . . . 28

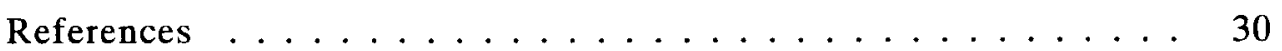

Appendix A: Example Problem ............... A1

SF 298

\section{List of Figures}

Figure 1. Definition sketch of relative depth, $\mathrm{d}_{1} / \mathrm{d}_{\mathrm{s}} \ldots \ldots . \ldots 2$

Figure 2. Stability number versus relative depth for breaking waves with no flow . . . . . . . . . . . . . 3 
Figure 3. Geometry and dimensions of L-shaped flume . . . . . . 6

Figure 4. Configuration for fixed-bed experiments $\ldots \ldots \ldots$

Figure 5. Toe stone sizes and locations .......... 8

Figure 6. Fixed-bed toe stability experiment . . . . . . . . 9

Figure 7. Configuration for movable-bed experiments ... . . 10

Figure 8. Comparison of $H_{d}$ with ebb flow velocity for each toe section ..................... 12

Figure 9. Stability number cubed as a function of relative depth . . 13

Figure 10. Stability number as a function of varying velocity parameters ................... 15

Figure 11. Variables $a$ and $b$ as a function of relative depth .... 18

Figure 12. Head-on view of unprotected jetty after scour . . . . 20

Figure 13. Side view of unprotected jety after scour . . . . . . 21

Figure 14. Head-on view of jetty with scoured area capped with a wide stone buttress ................ 21

Figure 15. Head-on view of jetty with wide stone buttress after irregular waves ................. 22

Figure 16. Head-on view of jetty with narrow stone buttress after

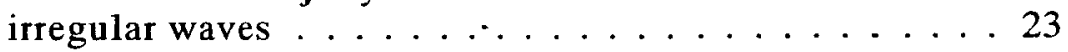

Figure 17. Head-on view of jetty with narrow stone buttress after

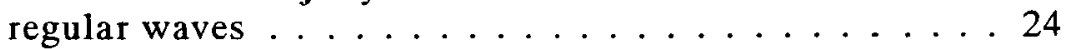

Figure 18. Views of bendway weir Plan BW-1 . . . . . . 25

Figure 19. Views of bendway weir Plan BW-2 . . . . . . 27

Figure A1. Actual and calculated stability numbers as a function of relative depth ...................... 


\section{Preface}

The work described in this report was authorized by Headquarters, U.S Army Corps of Engineers (HQUSACE), as part of the Coastal Problem Area of the Repair, Evaluation, Maintenance, and Rehabilitation (REMR) Research Program. The work was performed under Work Unit 32660, "Toe Stability in a Combined Wave and Flow Environment," for which Mr. D. D. Davidson, U.S. Army Engineer Waterways Experiment Station (WES), was Problem Area Leader.

Dr. Tony C. Liu was the REMR Coordinator at the Directorate of Research and Development, HQUSACE. Mr. Harold C. Tohlen and Dr. Liu served as the REMR Overview Committee. Mr. William F. McCleese (retired), WES, was the REMR Program Manager.

The study was conducted by personnel of the WES Coastal and Hydraulics Laboratory (CHL) under the general direction of Dr. James R. Houston, Director, and Charles C. Calhoun, Jr., Assistant Director, CHL, and under direct supervision of Mr. C. E. Chatham, Chief, Navigation and Harbors Division (CN), and Mr. Davidson, Chief, Coastal Structures Branch (CN-S). The study was designed and planned by Mr. Ernest R. Smith, Research Hydraulic Engineer, CN-S. Models were constructed and experiments were performed by Messrs. Leland L. Hennington, Civil Engineer, and Raymond Reed, Engineering Technician, under the supervision of Mr. Smith. Dr. Steven A. Hughes, Senior Research Scientist, CN, provided guidance for planning of movable bed experiments, and Mr. David L. Derrick, Research Hydraulic Engineer, River Sedimentation Engineering Branch, provided guidance and assistance in planning the bendway weir experiments.

At the time of publication of this report, Commander of WES was COL Robin R. Cababa, EN.

The contents of this report are not to be used for advertising, publication, or promotional purposes. Citation of trade names does not constitute an official endorsement or approval of the use of such commercial products. 


\section{Introduction}

\section{Background}

The design and construction of a stable structure toe is as important a part of a design or repair program for a rubble-mound structure as is the design and repair of the primary armor slopes. In many cases, an unstable toe will result in the failure of an otherwise adequately repaired structure. Markle (1986) found that toe instability was evident on the coastlines of the Atlantic and Pacific Oceans, the Gulf of Mexico, and the Great Lakes. All sites reporting toe instability were located in an environment in which both waves and flow were present.

Toe instability is not always easily diagnosed, because the toe is not usually visible from above the waterline. Many times toe instability is present but goes unnoticed until failure of the armor side slopes occurs. Additionally, toe stone is difficult to replace; therefore, it is important to determine the most stable and economical size for design and repair.

Under the U.S. Army Corps of Engineers' Repair, Evaluation, Maintenance, and Rehabilitation (REMR) Research Program, the U.S. Army Engineer Waterways Experiment Station was authorized and funded to conduct a work unit under the Coastal Research Problem Area entitled "Toe Stability in a Combined Wave and Flow Environment." The objective of the work unit was to evaluate the stability of toe stone repair armor when placed in a combined wave and ebb flow environment in order to develop design guidance for sizing stone for new or rehabilitation work.

Several studies have addressed scour at the toes of structures; however, few studies have been conducted to address stability of the toe armor. Previous research efforts to determine size and placement of toe stone have been conducted with waves only. Brebner and Donnelly (1962) and Tanimoto, Yagyu, and Goda (1982) conducted research on foundation and toe berm materials beneath or fronting vertical structures. Markle (1989) conducted two-and three-dimensional physical model experiments on a fixed bed to evaluate the stability of rubble-mound structure toes exposed to a breaking wave environment. The experiments did not address the combined effects of waves and river or tidal-induced flow. The outcome of Markle's study provided design guidance for sizing toe stone to be placed 
during the repair or rehabilitation of rubble-mound structure heads and trunks exposed to breaking waves.

Markle (1989) developed a relationship between toe stability number, $N_{s}$, and the depth ratio, $d_{1} / d_{s}$, of the toe berm for depth-limited breaking waves. The stability number is defined as

$$
N_{s}=\left(\frac{\gamma_{r}}{W_{r}}\right)^{1 / 3} \frac{H_{d}}{\left(S_{r}-1\right)}
$$

where

$\gamma_{r}=$ specific weight of an individual unit in pounds per cubic feet

$W_{r}=50$ percent size of an individual armor unit, $\mathrm{lb}$

$H_{d}=$ design wave height, that is, the highest wave height at the structure that causes no damage (wave height at which damage is $\leq 2$ percent)

$S_{r}=$ specific gravity of an individual armor unit relative to the water in which it is placed

$=\gamma_{r} / \gamma_{w}$ (where $\gamma_{w}=$ unit weight of water in which the structure is situated)

Depth ratio (illustrated in Figure 1) is defined as the depth to the top of the berm, $d_{1}$, normalized by the depth at the toe of the berm, $d_{s}$. The relationship of Markle (1989) for breaking waves is shown in Figure 2 and includes design curves developed previously by Brebner and Donnelly (1962) for vertical breakwaters subjected to a wave-only environment.

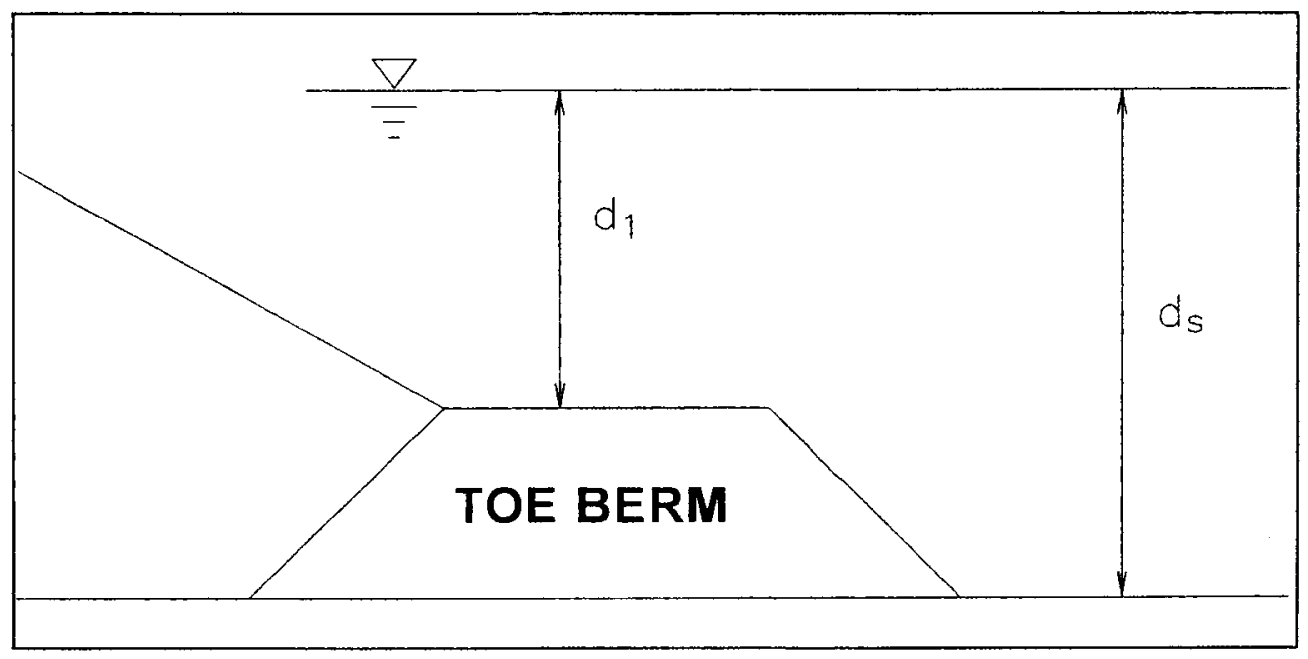

Figure 1. Definition sketch of relative depth, $d_{1} / d_{s}$ 


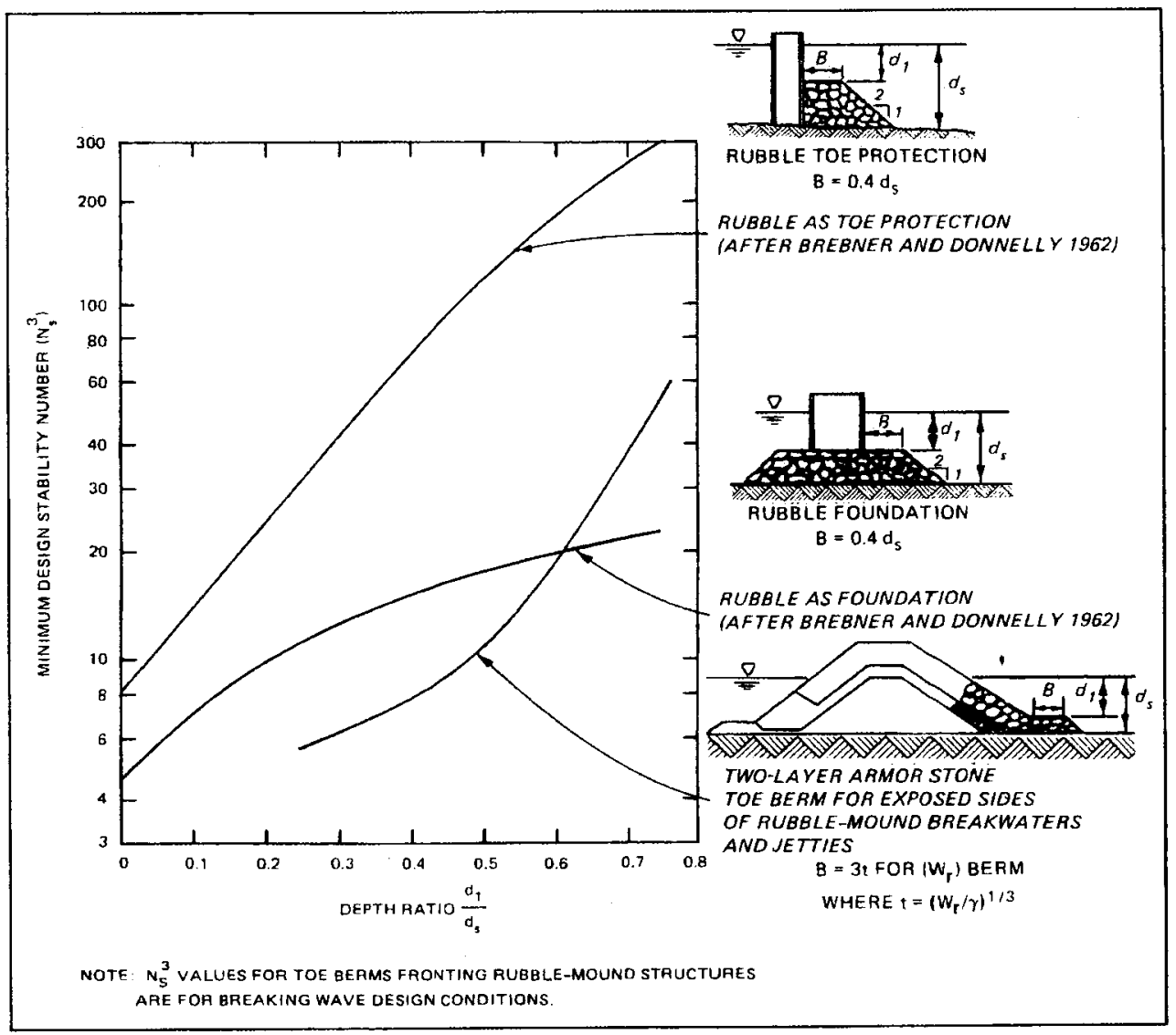

Figure 2. Stability number versus relative depth for breaking waves with no flow (Markle 1989)

For toe stone designed for nonbreaking waves, Markle (1989) recommended the guidance of the Shore Protection Manual (1984): toe stone armor weight no less than one tenth the weight of the primary armor stone required for acceptable stability.

\section{Study Purpose}

The purpose of the study was to develop a method for determining the size and placement of stone necessary to achieve a stable toe subjected to combined waves and flows. The study consisted of two phases, both of which were conducted using a three-dimensional physical model. The first phase was conducted on a fixed bed to determine proper size and placement of toe stone subjected to combined waves and ebb flow on a stable bottom. Guidance for size and placement of toe stone was developed for a range of wave heights and periods, water levels, and flow conditions. The second phase was conducted to determine the validity of the fixed-bed study results on a bottom that has potential for scour and undermining (movable bed). 
Chapter 2 describes the physical model and the facilities and equipment used in the experiments. Results of the study are discussed in Chapter 3 , and conclusions are summarized in Chapter 4 . 


\section{The Model}

\section{Design of Model}

A three-dimensional physical model was designed and constructed to simulate prototype conditions in which both waves and flow were present. The model jetty was non-site specific to allow the results to be applicable to any site that experiences combined waves and ebb flow. To minimize laboratory and scale effects, the model jetties were constructed at a generic midscale of approximately $1: 25$, model to prototype.

\section{Model Experiments}

\section{Facilities and equipment}

Experiments were conducted in an L-shaped basin having the dimensions $76.2 \mathrm{~m}$ long, 15 and $24.4 \mathrm{~m}$ wide, and $1.4 \mathrm{~m}$ deep in the study area (Figure 3). The model jetties were constructed on the flat bottom portion of the model area, which was constructed with a sandpit for use during the movable-bed experiments and capped with concrete during the fixed-bed experiments.

Waves were generated by a hinge-actuated electronically controlled hydraulic system. Displacement of the wave board was controlled by a command signal transmitted to the wave board by a computer, and waves were produced by the periodic displacement of the wave board. Random wave command signals to drive the wave board were generated to simulate a Texel Marsen Arsloe shallow-water spectrum (Hughes 1984) for the design wave periods. Regular wave signals were produced by a synthesized function generator to generate monochromatic waves.

Water surface elevations were recorded by single-wire capacitancetype gages, sampled at $20 \mathrm{~Hz}$. Three gages were placed "seaward" of the study section and were used to calibrate the facility and monitor incident wave heights. One gage was placed near the wave board to obtain offshore wave heights. The wave records obtained from the gages permitted 


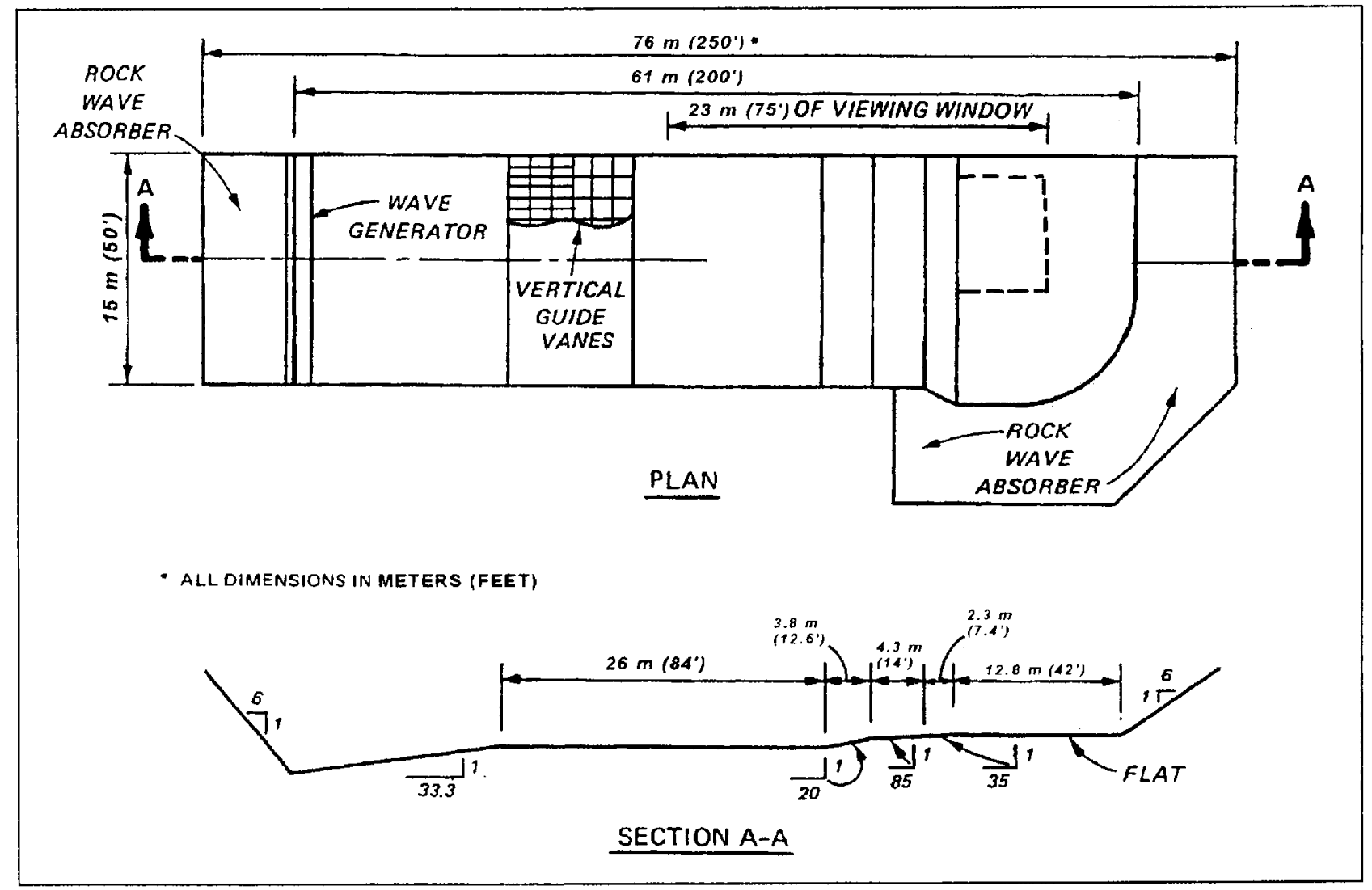

Figure 3. Geometry and dimensions of L-shaped flume

calculation of the average, significant, and zero-moment wave height and the peak and average period.

Conditions were selected to produce conditions that would allow the waves to shoal and break at the jetty for cases with and without ebb flow. Waves that encounter an opposing flow become steeper, and waves that normally would not break in a non-ebb flow environment could break if an opposing flow is present. Therefore, laboratory wave periods that produced waves of significant height to result in breaking at the jetty without an ebb flow present could also produce breaking waves in the presence of ebb flow.

Both regular and irregular waves were generated and calibrated with no flow up to the maximum (breaking) heights for wave periods between 1.7 and $3.0 \mathrm{sec}$ (approximately 8.5 to $15 \mathrm{sec}$, prototype) for water depths of 0.24 and $0.30 \mathrm{~m}(0.8$ and $1.0 \mathrm{ft})$.

A circulation system was constructed to generate ebb flow. The pump intake abutted the basin wall to minimize interference with incident waves, and ebb flow currents were introduced at a manifold, shown in Figure 4. The system had the capability of generating ebb flows up to $0.6 \mathrm{~m} / \mathrm{s}(2 \mathrm{ft} / \mathrm{s})$ (approximately $3 \mathrm{~m} / \mathrm{s}(10 \mathrm{ft} / \mathrm{s})$ prototype). 


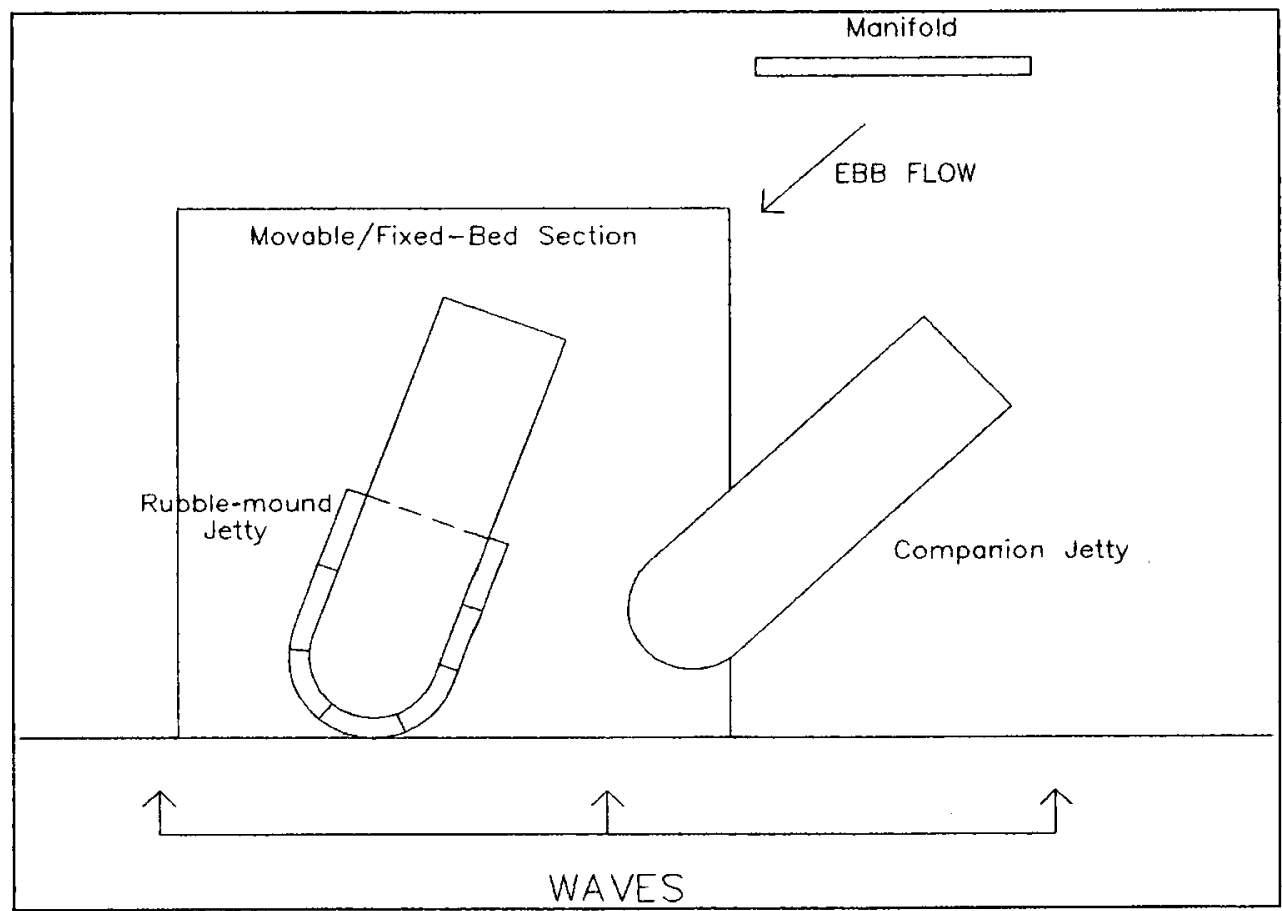

Figure 4. Configuration for fixed-bed experiments

Ebb flow currents were calibrated for a range of flows prior to experiments using a current meter placed in the center of the channel between the model jetties. Currents measured in the model channel were associated with discharge readings obtained from the flow meter installed in the pumping system.

\section{Procedures}

The study consisted of two phases: fixed and movable bed. Toe stability can be affected either directly by waves and currents or indirectly through undermining of the sand bed. Therefore, it was desired to obtain a method to determine appropriate stone sizes on a stable bed (Phase 1), and apply and verify the results on a movable bed (Phase 2).

Fixed-bed configuration. For fixed-bed experiments, the research jetty consisted of a rubble-mound jetty, modeled on the order of 1:25 prototype to model, and a companion jetty. The research jetty was oriented at a 70-deg angle to wave attack (Figure 4). The companion jetty was placed near the research jetty to reproduce reflections common to twinjetty inlets, and also to assist in directing current flow.

The research jetty was approximately $5 \mathrm{~m}(16 \mathrm{ft})$ long and consisted of two sections. The shoreward section was constructed of plywood with stones attached to the face. This surface was found to reproduce reflections similar to that of a rubble-mound structure, and was convenient to 
use in place of a rubble-mound structure because it did not require rebuilding and could be easily transported to other parts of the model. The seaward section was built as a rubble-mound structure using dolosse as an armor unit. It was desired to build a section of highly stable primary armor units so that the instability at the toe would be isolated.

Toe stone was placed around the study section in the manner recommended by Markle (1989), i.e., three stones wide and two stones high. To maximize efficiency of the experiments, the perimeter of the rubblemound jetty consisted of seven toe stone sections, each of which contained a different stone size. Toe failure may occur for certain wave and flow conditions in a section containing a heavier stone, whereas a lighter stone may be stable in a different section because of the interaction of the structure position and shape with the waves and currents. Therefore, the stones were color coded by size, which helped identify areas vulnerable to particular wave and ebb flow conditions. A schematic of the toe sections is shown as Figure 5, and a photograph of the rubble-mound jetty and the toe stone sections during fixed-bed experiments is shown as Figure 6.

Experiments were initiated with regular waves at a low wave height for a fixed period, ebb flow, and depth. To minimize oscillations in the basin, regular waves were generated in five bursts of 3 min each per wave height. The number of berm stones displaced was recorded after each wave burst, and percent damage was calculated for each toe berm section.

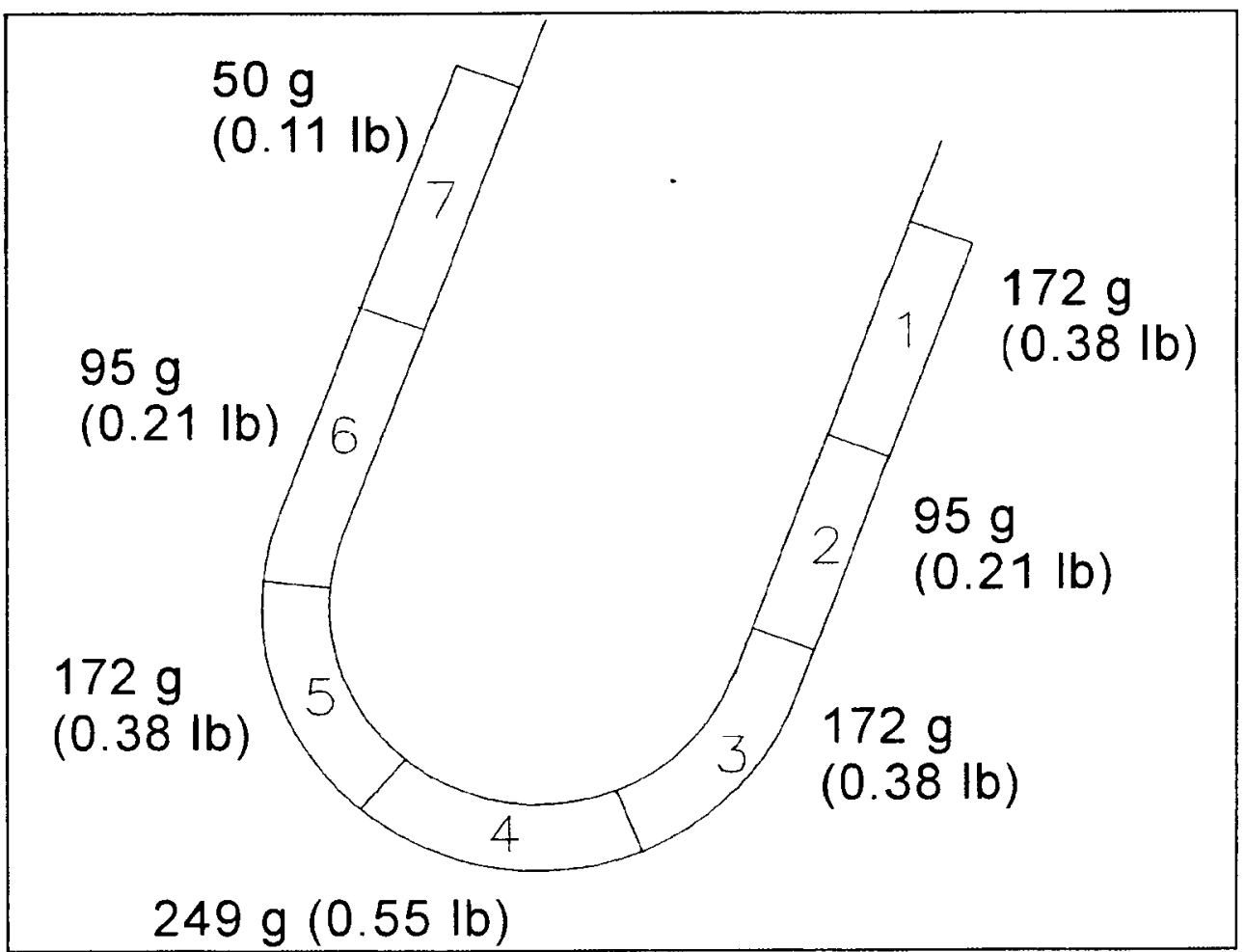

Figure 5. Toe stone sizes and locations 


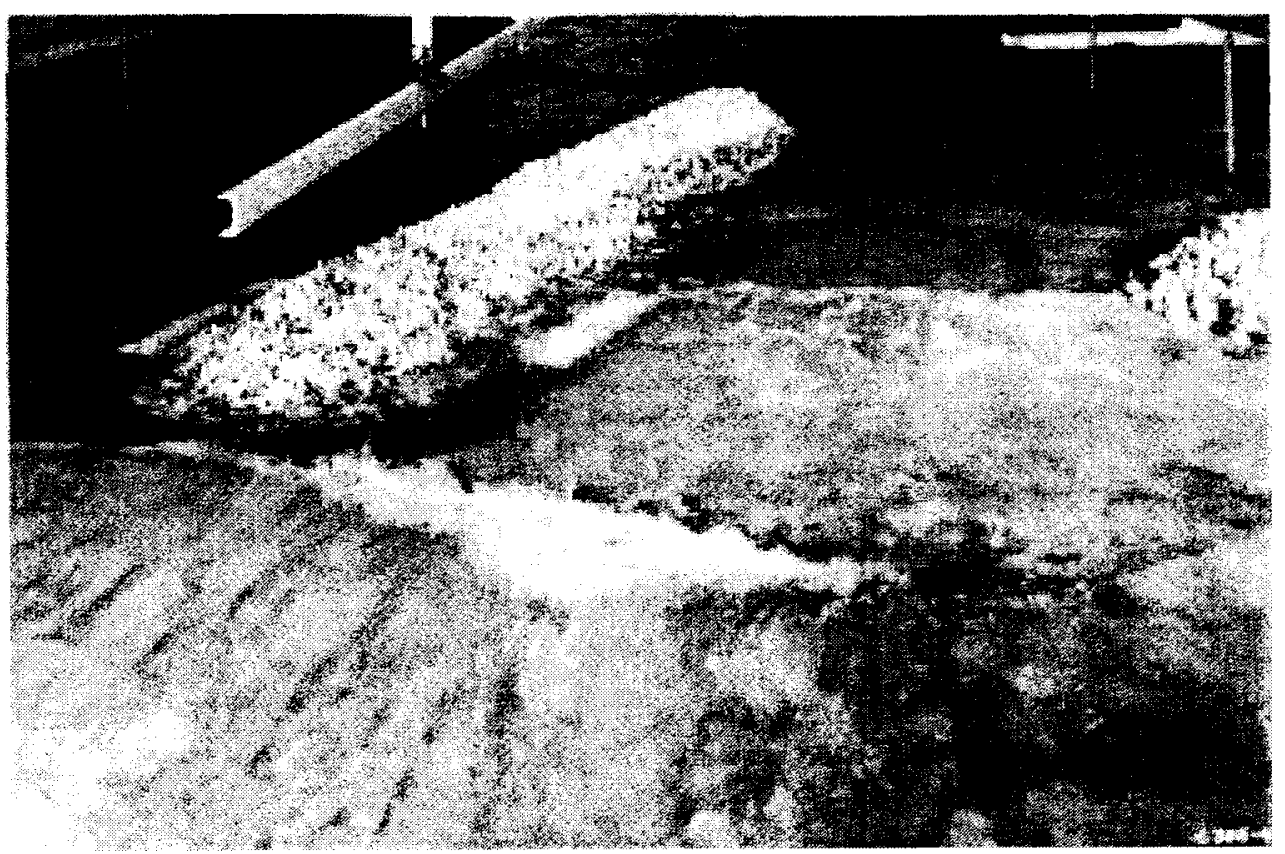

Figure 6. Fixed-bed toe stability experiment

After completion of a series of five wave bursts, the wave height was increased slightly and the procedure was repeated. Wave height was increased up to and beyond the breaker height. Toe berm damage was observed and repaired. Then, wave period, ebb flow, or depth was varied, and the previous steps were repeated.

Irregular wave experiments were conducted in the same manner as the regular wave experiments except waves were generated in a single 15 -min cycle rather than five bursts of $3 \mathrm{~min}$ each. This procedure was used with irregular waves because a longer record of data was required to establish a statistically strong wave spectrum.

Movable-bed configuration. The concrete-capped floor used for fixed-bed experiments was replaced with a $0.46-\mathrm{m}$ (18-in.) layer of sand having a mean diameter of $0.12 \mathrm{~mm}(0.004 \mathrm{in}$.) for movable-bed experiments. A rubble-mound stone jetty was constructed and oriented perpendicular to the incident wave direction, and ebb flow was directed parallel to the jetty (Figure 7). All waves and currents were generated at a $0.30-\mathrm{m}$ $(1.0-\mathrm{ft})$ water depth.

The purpose of the movable-bed experiments was to develop toe stability guidance based on results obtained from fixed-bed experiments on a bed that is unstable. The experiments were designed to simulate a repaired condition of a structure. Therefore, sand was allowed to scour around the structure, and the damage was repaired with a buttress of stone. The toe stone size for the repair was selected based on results of the fixed-bed experiments. Results from the movable-bed experiments 


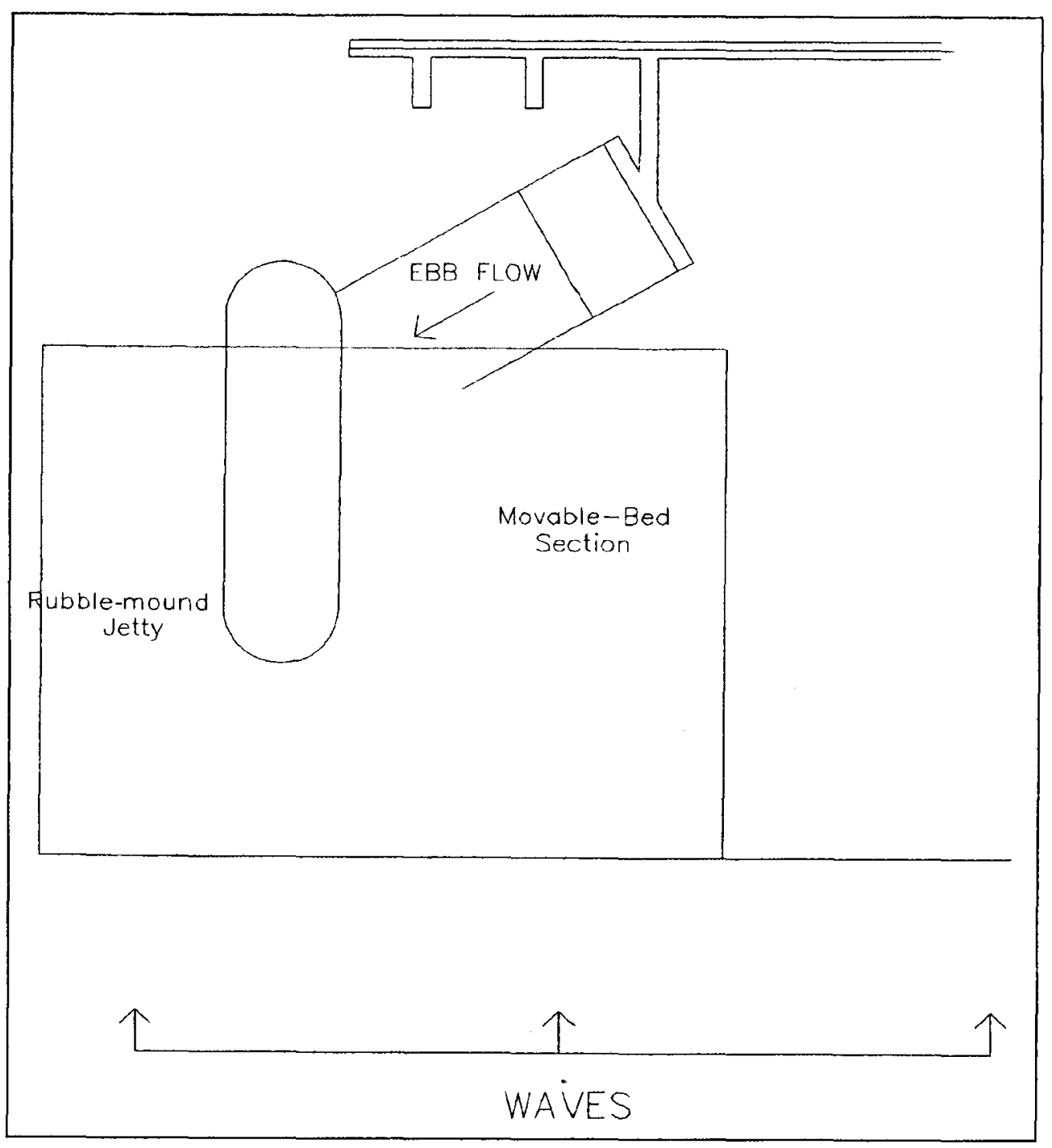

Figure 7. Configuration for movable-bed experiments

were qualitative; the toe stone size selected was either successful or unsuccessful in stabilizing the jetty toe. 


\section{Results}

\section{Fixed-Bed Experiments}

Fixed-bed experiments were conducted for regular waves having periods of 1.7, 1.87, and $3.0 \mathrm{sec}$ and initial ebb flows of $0.0,0.15 \mathrm{~m} / \mathrm{s}$ $(0.5 \mathrm{ft} / \mathrm{s}), 0.30 \mathrm{~m} / \mathrm{s}(1.0 \mathrm{ft} / \mathrm{s})$, and $0.46 \mathrm{~m} / \mathrm{s}(1.5 \mathrm{ft} / \mathrm{s})$ between the jetties at water depths of $0.24 \mathrm{~m}(0.8 \mathrm{ft})$ and $0.30 \mathrm{~m}(1.0 \mathrm{ft})$. At a nominal model scale of $1: 25$, model to prototype, the experiment conditions would represent prototype periods of 8.5 to $15 \mathrm{sec}$, ebb flows of 0.0 to $2.3 \mathrm{~m} / \mathrm{s}$ $(7.5 \mathrm{ft} / \mathrm{s})$, and water depths between $6.0 \mathrm{~m}(19.7 \mathrm{ft})$ and $7.5 \mathrm{~m}(24.6 \mathrm{ft})$, which are common to many inlets in the United States.

During the experiments, it was noted that the difference in damage that occurred between no-flow conditions and the $0.15-\mathrm{m} / \mathrm{s}(0.5-\mathrm{ft} / \mathrm{s})$ flow condition was minimal. This indicated that the $0.15-\mathrm{m} / \mathrm{s}(0.5-\mathrm{ft} / \mathrm{s})$ ebb condition did not affect toe instability significantly more than conditions with waves only, and was eliminated from further experiments. Conversely, damage with waves and current increased dramatically between the $0.30-\mathrm{m} / \mathrm{s}(1.0-\mathrm{ft} / \mathrm{s})$ and $0.45-\mathrm{m} / \mathrm{s}(1.5-\mathrm{ft} / \mathrm{s})$ flow conditions. Therefore, a $0.38-\mathrm{m} / \mathrm{s}(1.25-\mathrm{ft} / \mathrm{s})$ flow condition was included in the experiments to provide supplemental data between the $0.30-\mathrm{m} / \mathrm{s}(1.0-\mathrm{ft} / \mathrm{s})$ and $0.45-\mathrm{m} / \mathrm{s}$ $(1.5-\mathrm{ft} / \mathrm{s})$ currents.

Toe stability experiments with ebb-flow currents also were conducted for irregular wave conditions using peak wave periods, $T_{p}$, of 1.87 and $3.0 \mathrm{sec}$ for the same flow conditions and water depths used for regular wave experiments. Damage was observed to be less with irregular waves due to smaller, nonbreaking waves included in the wave signal. However, similar results between regular and irregular waves would be expected if irregular waves were generated for a longer length of time, thus accumulating more time with the higher waves in the time series.

\section{Qualitative results}

Both qualitative and quantitative results were obtained during the study. Observations, or qualitative results, indicated that for a given ebb flow condition, a wave condition existed that would cause a pulsating 
effect at the toe berm. This effect was a result of the waves breaking and running up the structure, then running down the structure. When waves ran up the structure, the water surface elevation was at a maximum, the orbital current velocities of the waves opposed the ebb current velocities, and the net current flow was at a minimum. However, during rundown, the water surface elevation decreased and the wave orbital velocities and ebb current velocities were in phase. For this condition, the net velocity was at a maximum and the water surface elevation was at a minimum, which reduced the flow volume, and by continuity, the velocity increased.

The effect of ebb flow on toe stability is shown in Figure 8, which illustrates the comparison of $H_{d}$ with magnitude of flow for a fixed wave period for each berm section (defined in Figure 5). Because $H_{d}$ is the height that causes 2 percent damage, it is inversely proportional to damage of a structure. Therefore, Figure 8 also gives a comparison of percent damage to each section. This figure shows that the damaging wave height is highest (i.e., less damage to the section) for low-flow conditions; slightly less for flows of $0.30 \mathrm{~m} / \mathrm{s}(1.0 \mathrm{ft} / \mathrm{s})$; and lowest for $0.45-\mathrm{m} / \mathrm{s}$ (1.5-ft/s) flows.

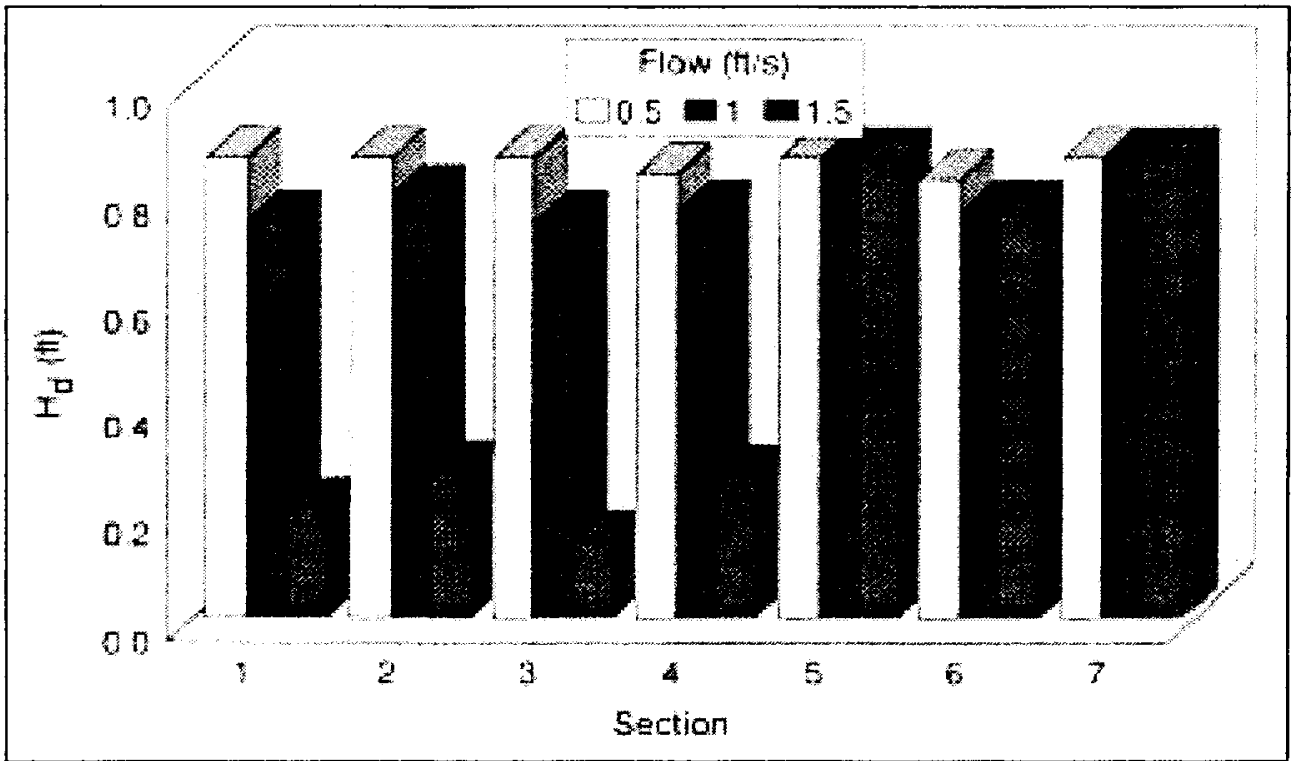

Figure 8. Comparison of $H_{d}$ with ebb flow velocity for each toe section

Design wave height was near constant for Sections 5,6 , and 7 (the outer sections) because current did not flank the cells and most of the wave energy had dissipated seaward of those cells. The decrease in $H_{d}$ with ebb flow for Sections 1 through 4 is caused by the current modifying the incident wave shape. As waves approach the structure and encounter an opposing current, they become steeper and break at lower wave heights than waves with no flow present. Therefore, waves that normally would not damage a structure could cause damage if a flow were present. Additionally, observations showed that damage did not increase significantly 
for waves higher than the damaging height with flow conditions, since breaking occurred farther offshore of the structure and the waves were broken as they propagated to the jetty.

\section{Quantitative results}

Quantitative results were obtained by determining the damage of each cell for a given wave and flow condition. Sections were considered not damaged if 2 percent or less of the total stones in the section were displaced. A total of 125 stability numbers were determined from the experiments using Equation 1. These numbers were obtained by varying wave period, ebb flow velocity, water depth, and stone size to determine $H_{d}$ and, thus, $N_{s}$.

Stability number cubed versus relative depth of the toe berm for all stability experiments, including experiments with both regular and irregular waves, is shown in Figure 9 with the minimum stability line developed by Markle (1989). The wide range of $N_{s}^{3}$ values that occur at each relative depth is due to the combination of factors that affect stability, including ebb flow velocity, depth, stone size, and wave height. As part of the study, it was important to consider a broad range of these factors to determine combinations that produced minimum stability numbers, which would lead to determining the proper toe stone weight. The figure shows that $N_{s}^{3}$ values for waves and no-flow conditions are greater than minimum values obtained by Markle, which compares favorably with Markle's results. Also, stability numbers for waves with a $0.15-\mathrm{m} / \mathrm{s}(0.5-\mathrm{ft} / \mathrm{s}) \mathrm{ebb}$

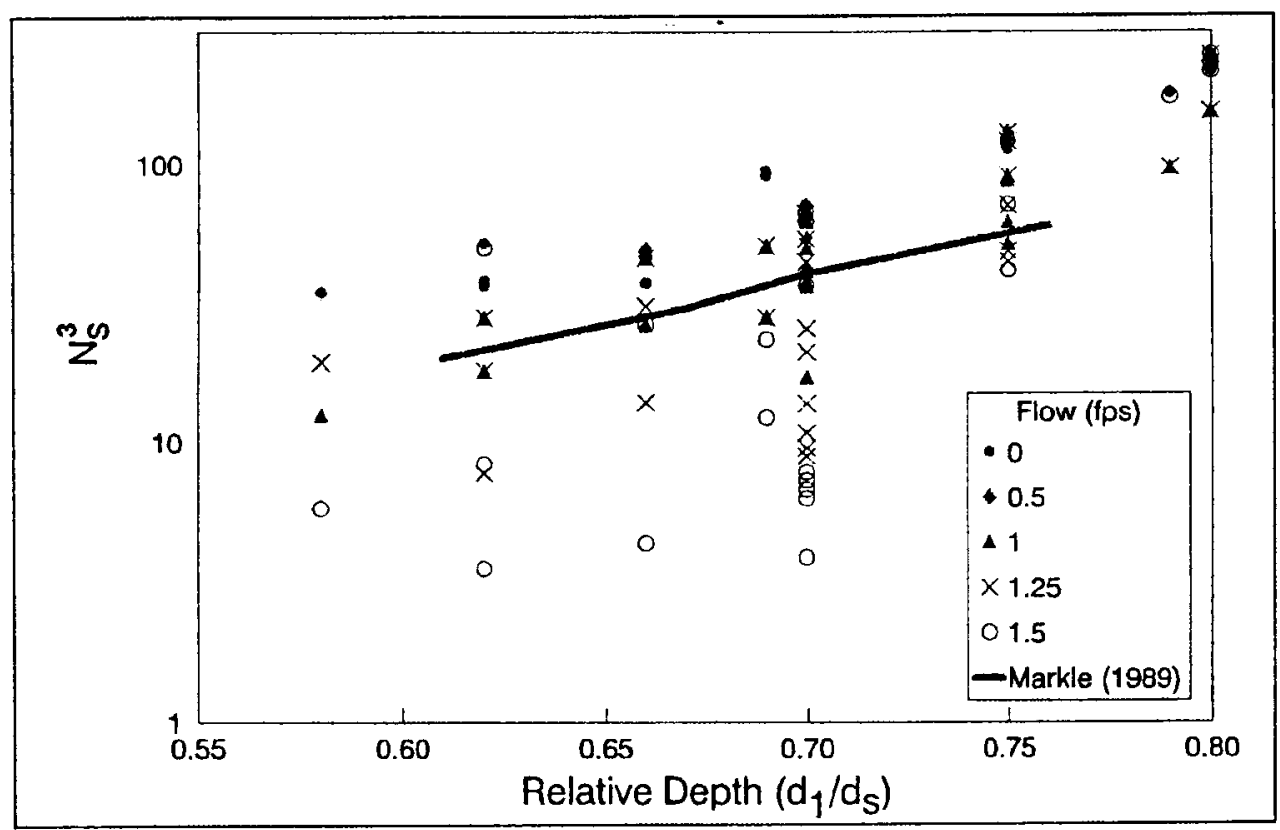

Figure 9. Stability number cubed as a function of relative depth 
flow are above the minimum values of Markle. However, as flow increases, stability numbers decrease significantly (i.e., damage to the toe stability cells increased), and a heavier stone weight would be required to provide a stable toe.

It was desired to relate $N_{s}$ to a nondimensional variable that considered the factors which influence toe stability. Considering the observation of a "pulsating" effect that occurred as waves ran down the jetty slope (discussed earlier in the chapter), the sum of ebb flow velocity, $U$, and the maximum horizontal orbital wave velocity, $u$, were normalized by $\left(g d_{s}\right)^{1 / 2}$, the theoretical shallow-water wave celerity. Assuming linear wave theory and only the case of maximum velocity, $u$ may be calculated from the following:

$$
u=\frac{g T H_{d}}{2 L}
$$

in which $g$ is acceleration due to gravity, $T$ is peak wave period (in seconds), and $L$ is the local wave length.

An equation was developed to determine minimum $N_{s}$ as a function of the nondimensional parameter by performing regression analysis on individual series of $d_{1} / d_{s}$ between 0.58 and 0.75 (Figure 10). Little damage occurred at $d_{l} / d_{s}=0.80$ (Section 7), and these data were not included in the analysis. To determine a stable toe size for breaking waves and ebb flow (the worst cases for stability), regression analysis was performed on the lower envelope, or minimum values of $N_{s}$. Figure 10 shows the resulting equation and the correlation coefficient, $R^{2}$, from regression analysis. The data at each relative depth show a common trend; however, only two minimum data points were available for $d_{l} / d_{s}=0.58$ and four for $d_{1} / d_{s}=0.69$. The common equation from regression analysis takes the form of

$$
N_{s}=a\left(\frac{U+u}{\sqrt{g d_{s}}}\right)^{b}
$$

Figure 11 shows the variables $a$ and $b$, respectively, plotted as a function of $d_{1} / d_{s}$. Unfortunately, few $N_{s}$ values were available for $d_{1} / d_{s}=0.58$ and 0.69 (noted as hollow points in Figure 11). Since these values were not consistent with the other data points, it was necessary to assume that they were outlying points.

The data show that values of $a$ increase from $d_{1} / d_{s}=0.62$ to a limit of approximately 8.3 and remain relatively constant for higher values of relative depth. According to Equation 3, this would indicate that $N_{s}$ also would reach a constant value at some relative depth. However, this is inconsistent with the actual stability number, which varies with $d_{1} / d_{s}$ because both $N_{s}$ and $d_{l} / d_{s}$ are a function of stone size. Therefore, $a$ was assumed to vary for all relative depths, and the slope of the line between 


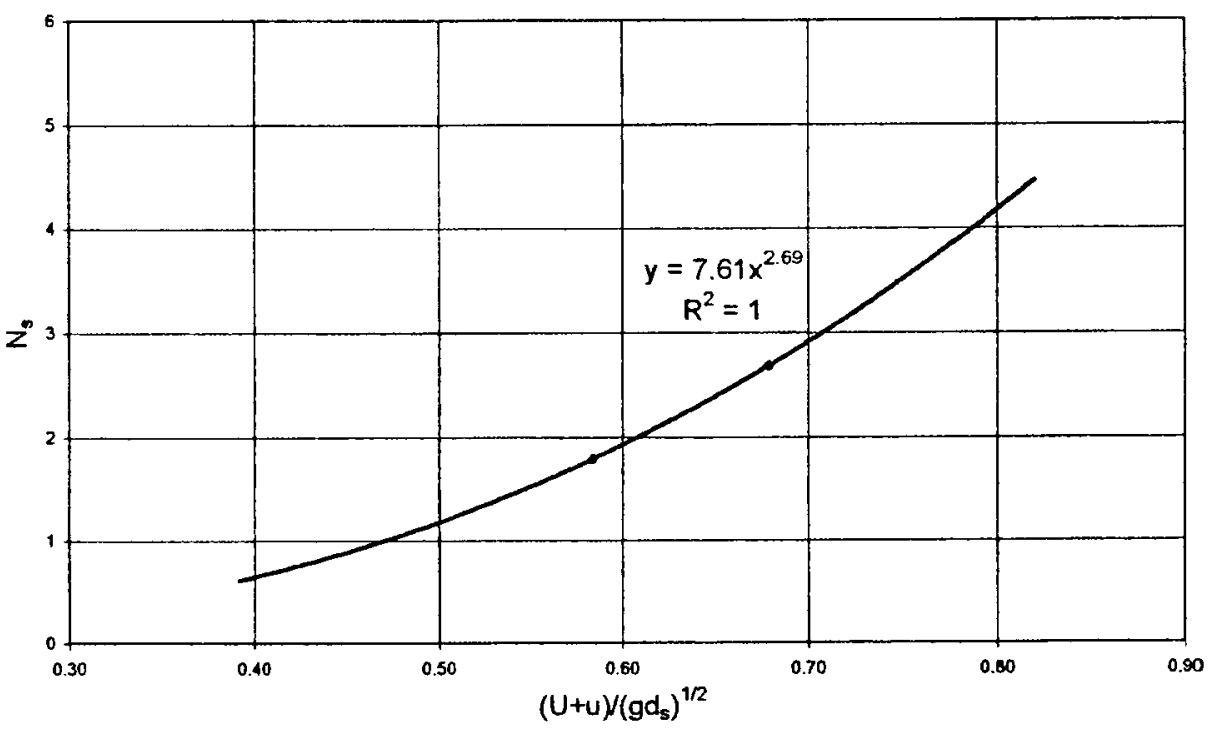

a. $d_{1} / d_{s}=0.58$

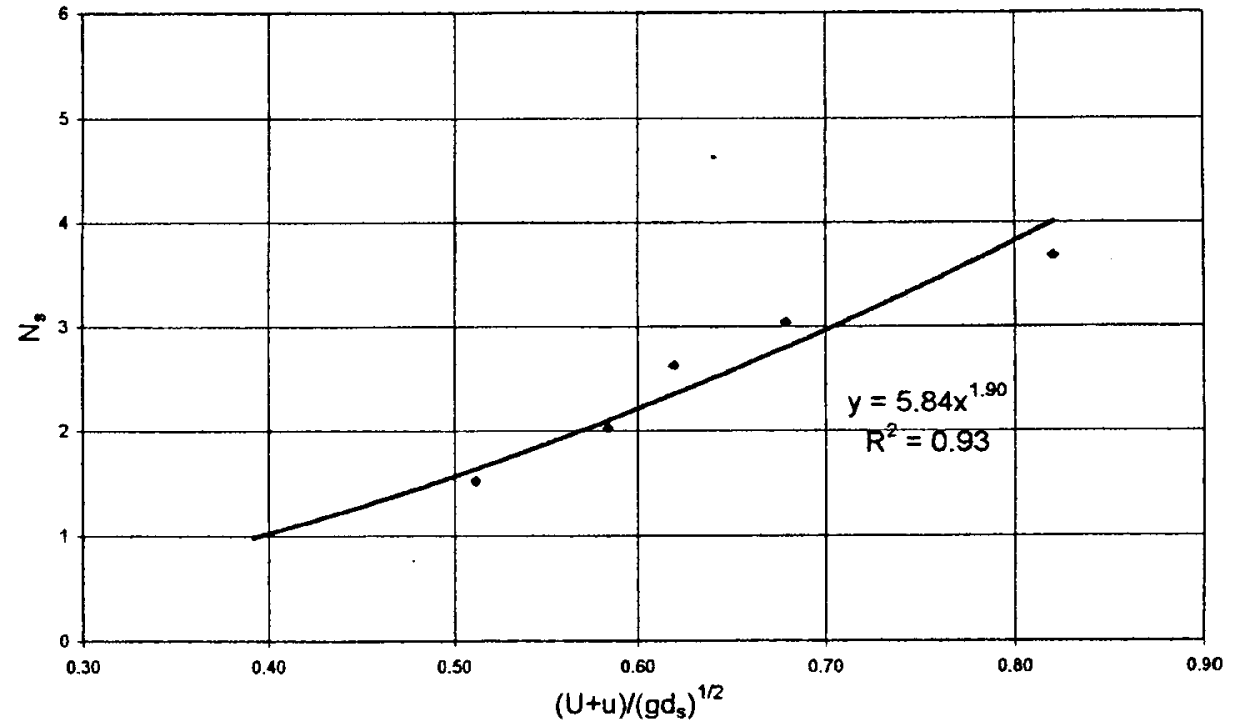

b. $d_{1} / d_{s}=0.62$

Figure 10. Stability number as a function of varying velocity parameters (Sheet 1 of 3 ) 


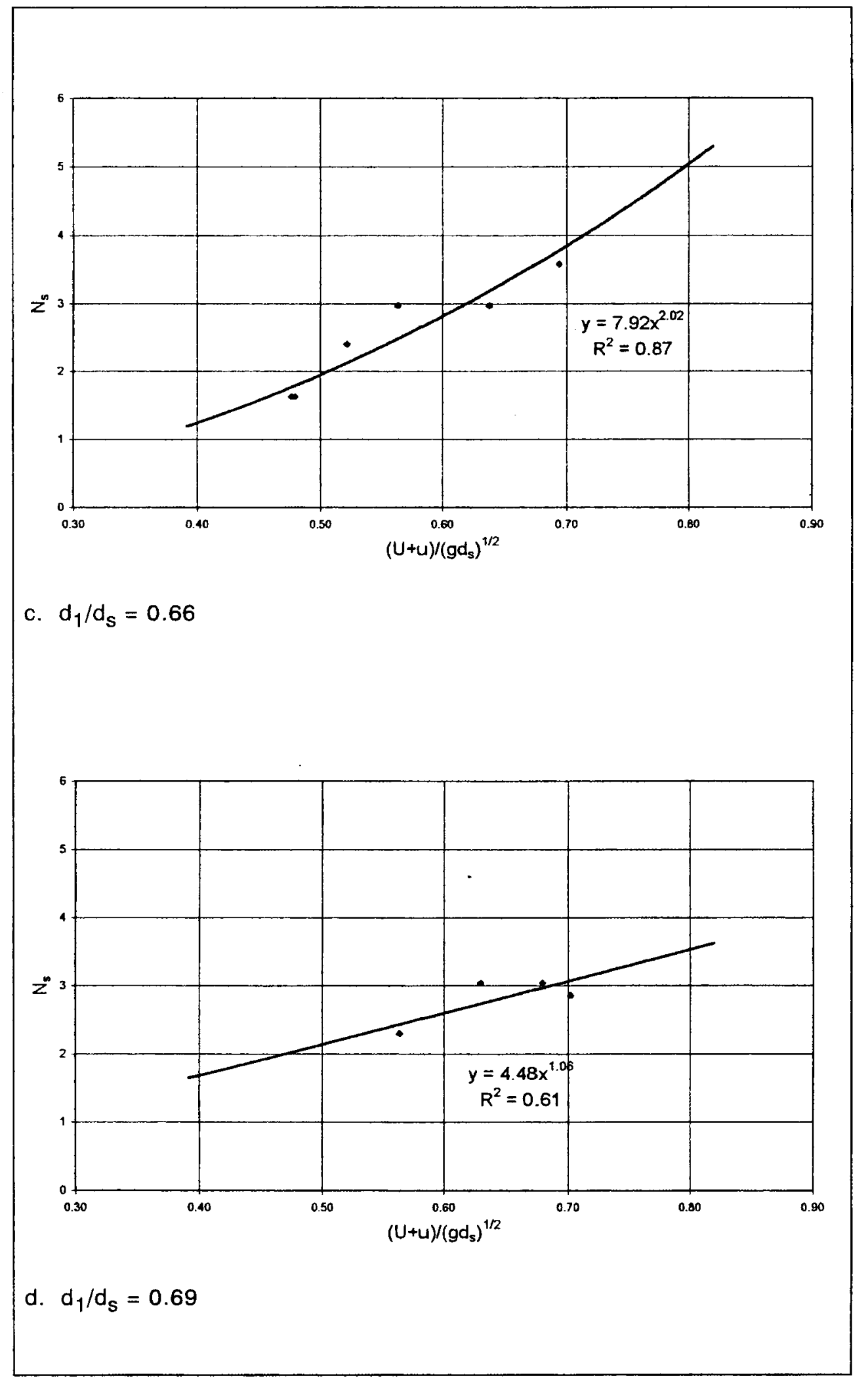

Figure 10. (Sheet 2 of 3 ) 


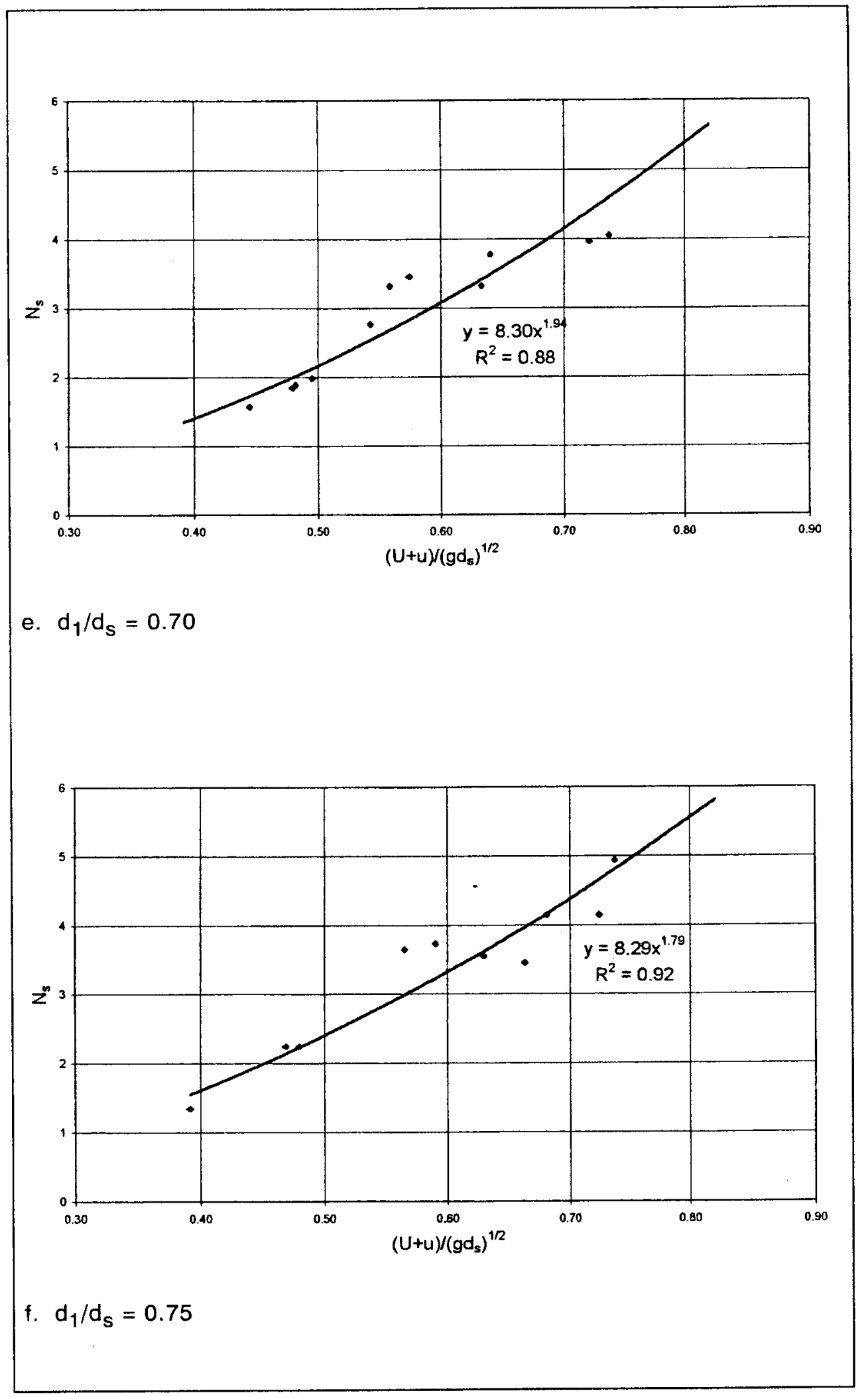

Figure 10. (Sheet 3 of 3 ) 


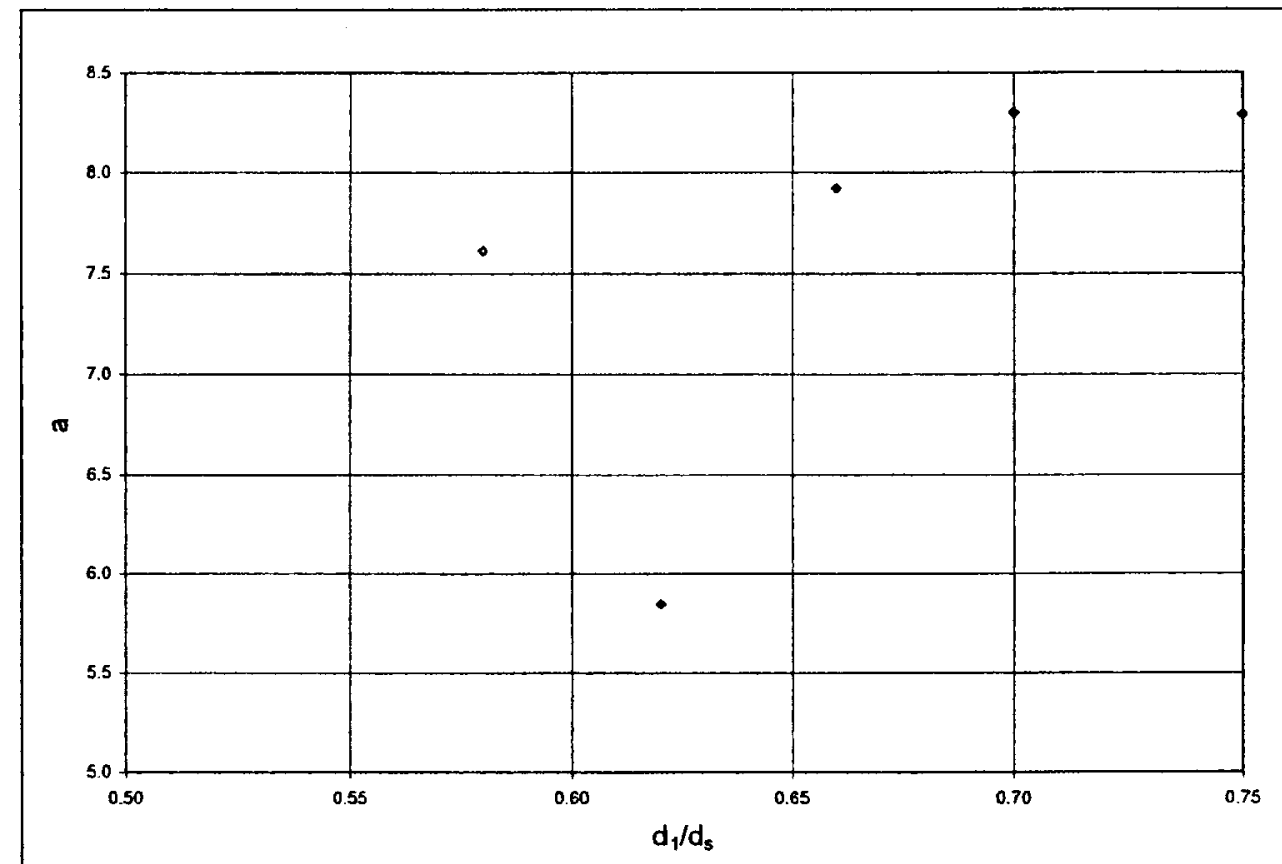

a. Variable a

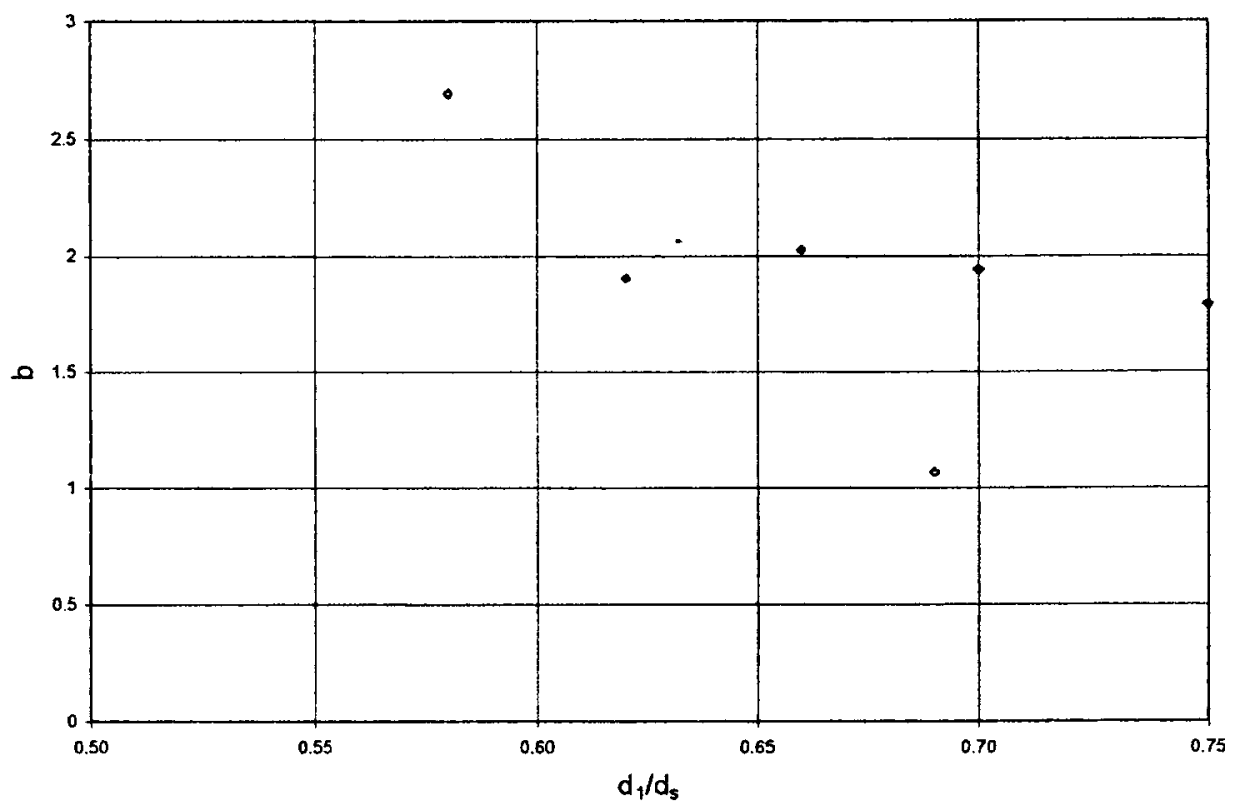

b. Variable $b$

Figure 11. Variables $a$ and $b$ as a function of relative depth 
$d_{1} / d_{s}=0.62$ and $d_{1} / d_{s}=0.66$ was used to calculate $a$. Values of $b$ vary little and are essentially constant, with an average of 1.9 . Little difference was found between predicted values using $b=1.9$ or $b=2$; therefore, for simplicity, the value was set at 2 . The final form of the equation is

$$
\left(N_{s}\right)_{c}=a\left(\frac{U+u}{\sqrt{g d_{s}}}\right)^{2}
$$

where $\left(N_{s}\right)_{\mathrm{c}}$ is the calculated stability number and the variable $a$ is defined as

$$
a=51.0\left(\frac{d_{1}}{d_{s}}\right)-26.4
$$

Equation 4 is valid over the range of relative depths studied, 0.58 to 0.80 . It should be noted that $d_{1} / d_{s}$ is a function of stone size and $N_{s}$ is a function of stone weight, which also is a function of stone size. Therefore, the solution for a stable toe stone weight requires an iterative solution. It is recommended that the minimum weight of toe stone suggested by Markle (1989) for nonbreaking waves, one tenth the weight of the primary armor layer, be used as the initial selection of toe stone weight to compute $d_{1} / d_{s}$ and actual $N_{s}$. If $\left(N_{s}\right)_{c}$ is less than or equal to the actual $N_{s}$, the selected toe stone weight should sufficiently stabilize the toe.

However, if the calculated value is greater than the actual value, a heavier stone will be required and the above procedure repeated until a stone size is determined that yields $\left(N_{s}\right)_{c}<N_{s}$. An example problem of how to use this method is provided in Appendix A. Additionally, it is recommended that the toe stone weight should always be greater than one tenth the primary armor weight required for acceptable stability.

Equation 4 was based on physical model experiments employing a three-stone-wide buttress on a fixed bed. Stone weights computed using this method pertain only to minimum weight and buttress width to stabilize the toe. Scouring of underlying and neighboring sand is not included in the above analysis. Therefore, a wider buttress may be required to armor the underlying sand to prevent scouring and undermining of the structure.

\section{Movable-Bed Experiments}

\section{Analysis of results}

The facility was configured for movable-bed experiments by removing the concrete-capped floor and replacing it with sand, as described in Chapter 2 (Figure 7). The purpose of movable-bed experiments was to 
determine the validity of Equation 4 for a structure damaged due to toe failure by scour. Therefore, stone was placed around the jetty at the toe only to provide a blanket to prevent armor stone from subsiding into the underlying sand. No toe protection was installed, and waves and ebb flow were allowed to damage the structure. The jetty was subjected to an irregular wave series having a period, $T_{p}$, of $2 \mathrm{sec}$, breaking wave height of $0.26 \mathrm{~m}(0.86 \mathrm{ft})$, and ebb flow velocity of $0.40 \mathrm{~m} / \mathrm{s}(1.3 \mathrm{ft} / \mathrm{s})$. Waves and ebb flow were generated for 10 continuous hours to allow a scour hole to develop (Figures 12 and 13). The scour undercut the armor stone, which caused some of the lower armor to subside and become unstable. If the structure were exposed to additional waves and currents in this state, failure of the armor would occur.

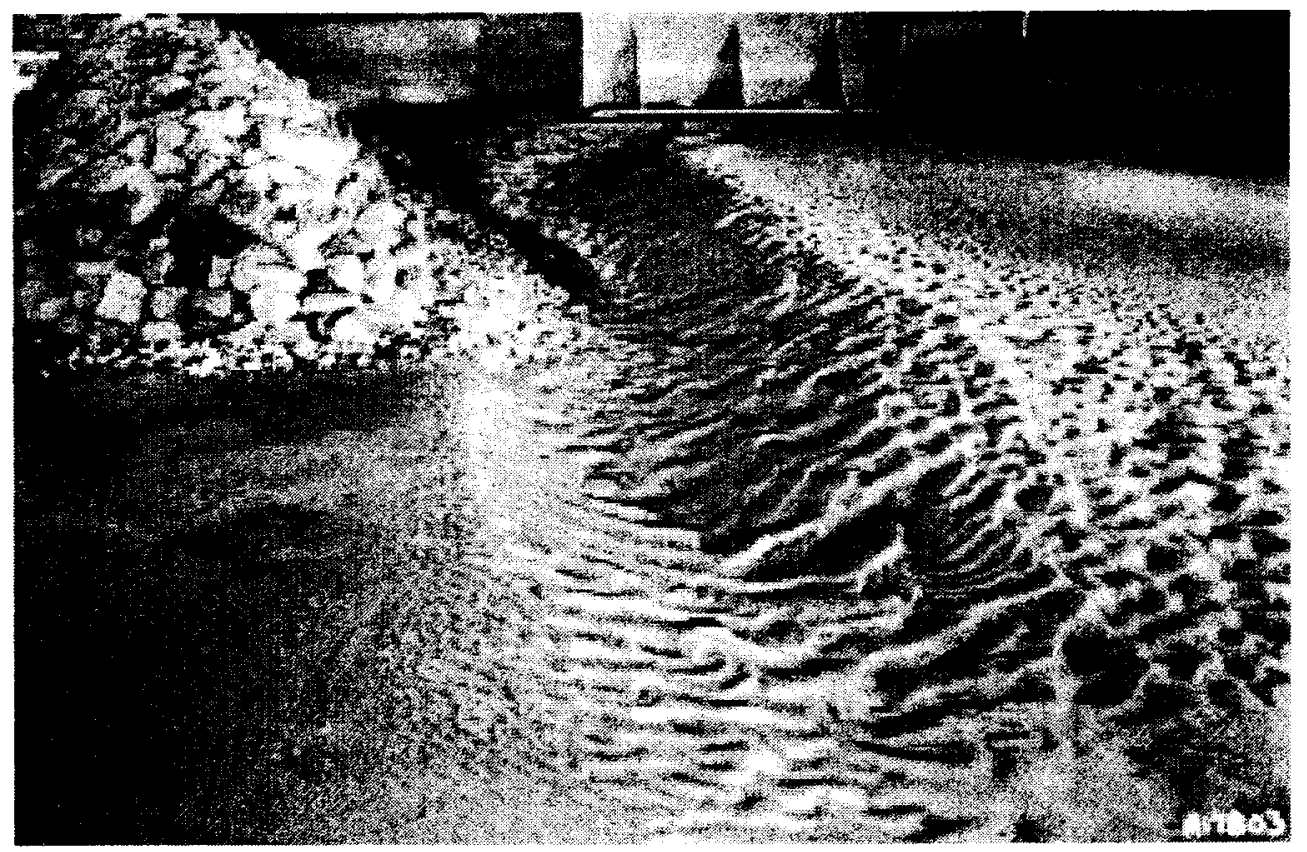

Figure 12. Head-on view of unprotected jetty after scour

A stone size was selected for use in a toe buttress based on Equation 4. The eroded sand was replaced in the scour hole and armored using 172-g $(0.38-1 b)$ stone placed in two layers over the width of scour (Figure 14). Unlike the fixed-bed experiments, only one toe stone size was used along the jetty perimeter in movable-bed experiments.

The wave and flow condition was generated for 10 additional hours, and the toe buttress remained in place throughout the test. However, scour occurred along the edge of the buttress (Figure 15). Despite scouring along the buttress edge, the experiment indicated that the stone size selected and placement scheme were stable for use on a movable bed.

To determine if less toe stone would be required to protect the structure, the sand bed was remolded and $172-\mathrm{g}(0.38-\mathrm{lb})$ stone was placed in 


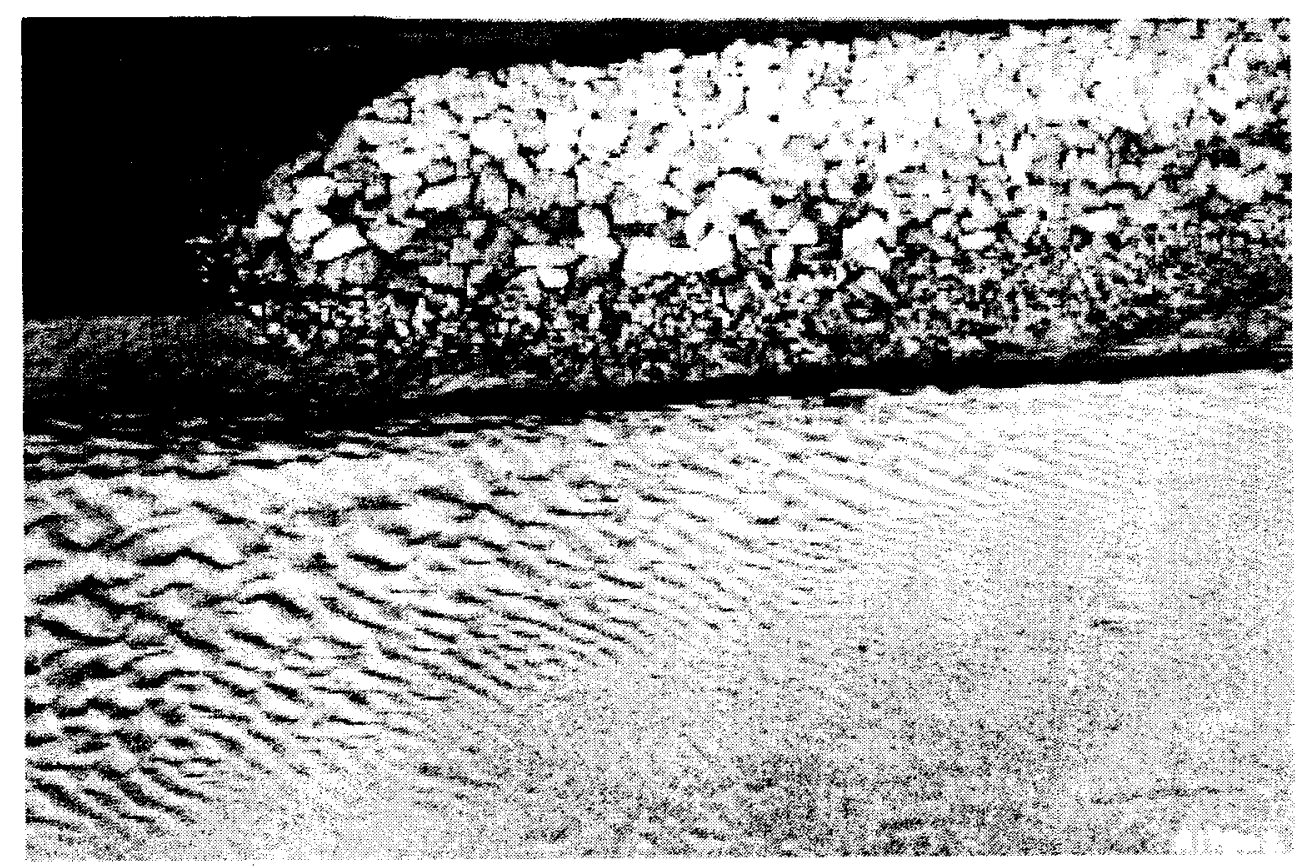

Figure 13. Side view of unprotected jetty after scour

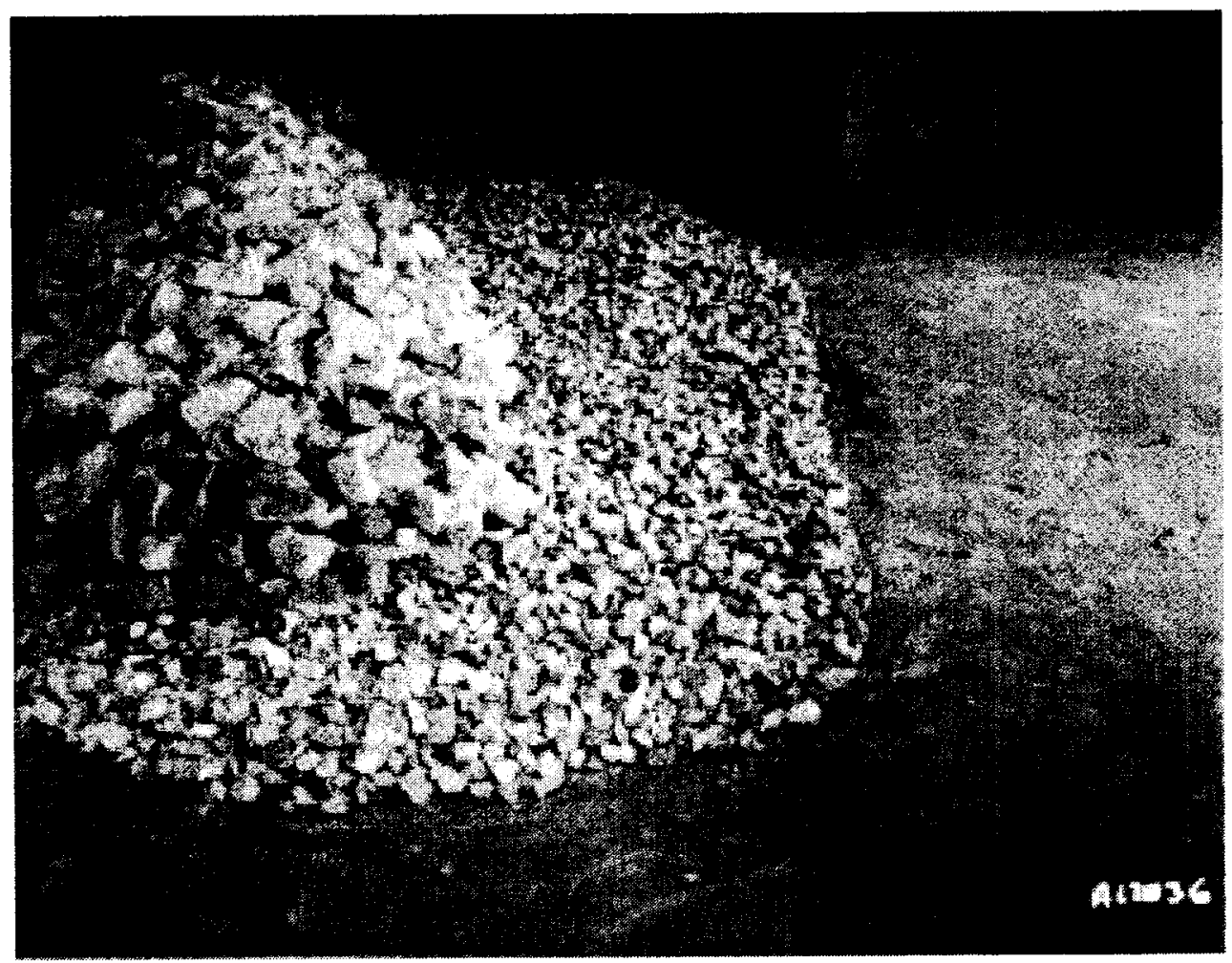

Figure 14. Head-on view of jetty with scoured area capped with a wide stone buttress 
two layers over an area that was half the width of the original scour hole. The wave and ebb flow condition was repeated for 10 hours. Although sand scoured along the outer boundary of the stone, the narrower buttress protected the structure toe and was stable for the condition (Figure 16).

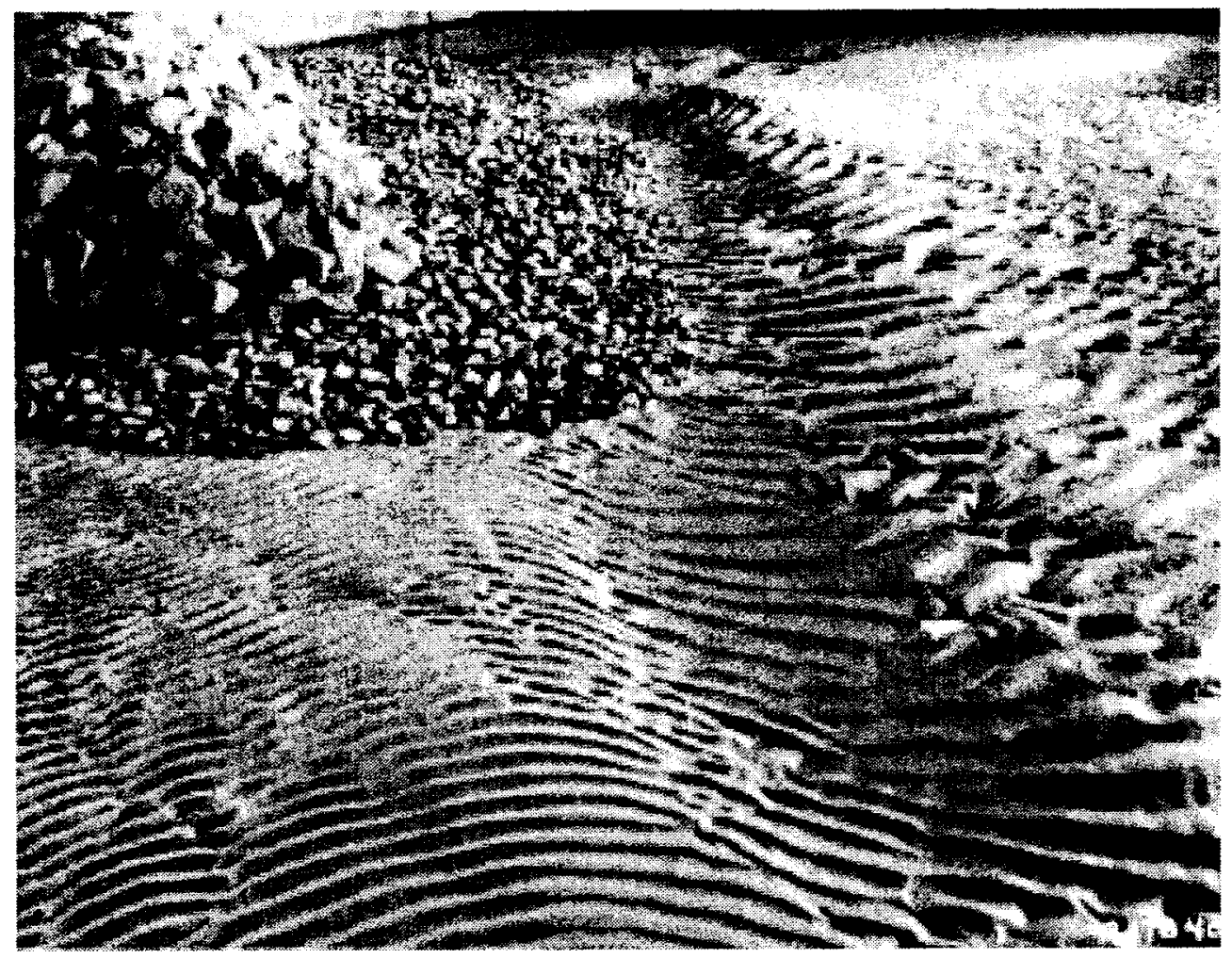

Figure 15. Head-on view of jetty with wide stone buttress after irregular waves

Additional experiments were conducted on the narrower buttress without remolding the sand or buttress, using an ebb flow velocity of $0.40 \mathrm{~m} / \mathrm{s}$ $(1.3 \mathrm{ft} / \mathrm{s})$, but with regular waves generated to have a period, $T$, of $2 \mathrm{sec}$ and a wave height of $0.26 \mathrm{~m}(0.86 \mathrm{ft})$. The regular-wave experiment was selected because waves of constant height would subject the toe buttress to the most severe conditions. After $10 \mathrm{hr}$ of continuous ebb flow and wave action, the structure was not damaged although scour occurred along the buttress (Figure 17).

Experiments continued on the narrower buttress for the $0.40-\mathrm{m} / \mathrm{s}$ (1.3-ft/s) ebb flow and breaking wave height of $0.26 \mathrm{~m}(0.86 \mathrm{ft})$, but a shorter irregular wave, $T_{p}=1.87 \mathrm{sec}$, was used. Shorter wave periods produce steeper waves and can cause additional wave breaking on the buttress. After $2 \mathrm{hr}$ of waves and ebb flow, no further damage had occurred to the edge of the toe buttress and the jetty toe was protected.

The experiments indicated that the method to select the appropriate weight for a stable toe stone size is valid for use on erodible beds. It is 


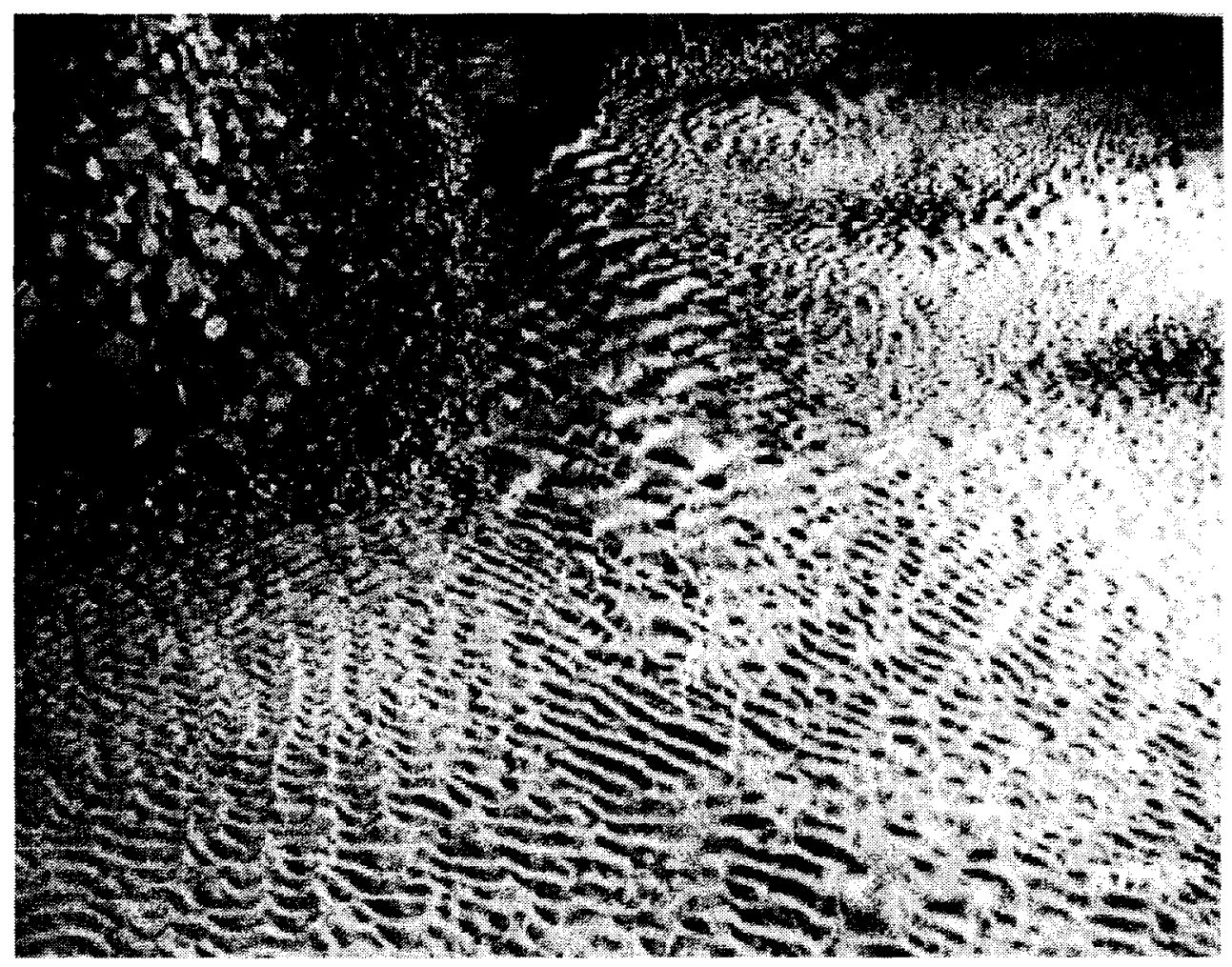

Figure 16. Head-on view of jetty with narrow stone buttress after irregular waves

recommended that the buttress be constructed two stone layers thick and half as wide as the scour hole or a minimum of three stones wide, whichever is greater.

\section{Bendway weir study results}

Bendway weirs were developed for use in riverine environments to direct channel flow and prevent erosion of channel banks. Weirs are submerged structures that can be constructed of any material. Flow direction is altered perpendicular to the weir as flow passes over the structure. A series of weirs placed in a river can control the navigation channel. Mr. John H. Lockhart, former Coastal Technical Monitor of the REMR Program, suggested investigating the use of bendway weirs as a possible alternative to coastal toe protection. Mr. Dave Derrick of the Coastal and Hydraulics Laboratory was consulted prior to and during experiments with bendway weirs. Mr. Derrick helped develop bendway weirs for riverine application and has worked extensively in this field.

A series of weirs was constructed using 172-g (0.38-lb) stone placed two layers thick, three stones wide, and extended perpendicular to the breakwater at a length that covered the original scour hole generated during previous ebb flow movable-bed tests (Plan BW-1, Figure 18a). 


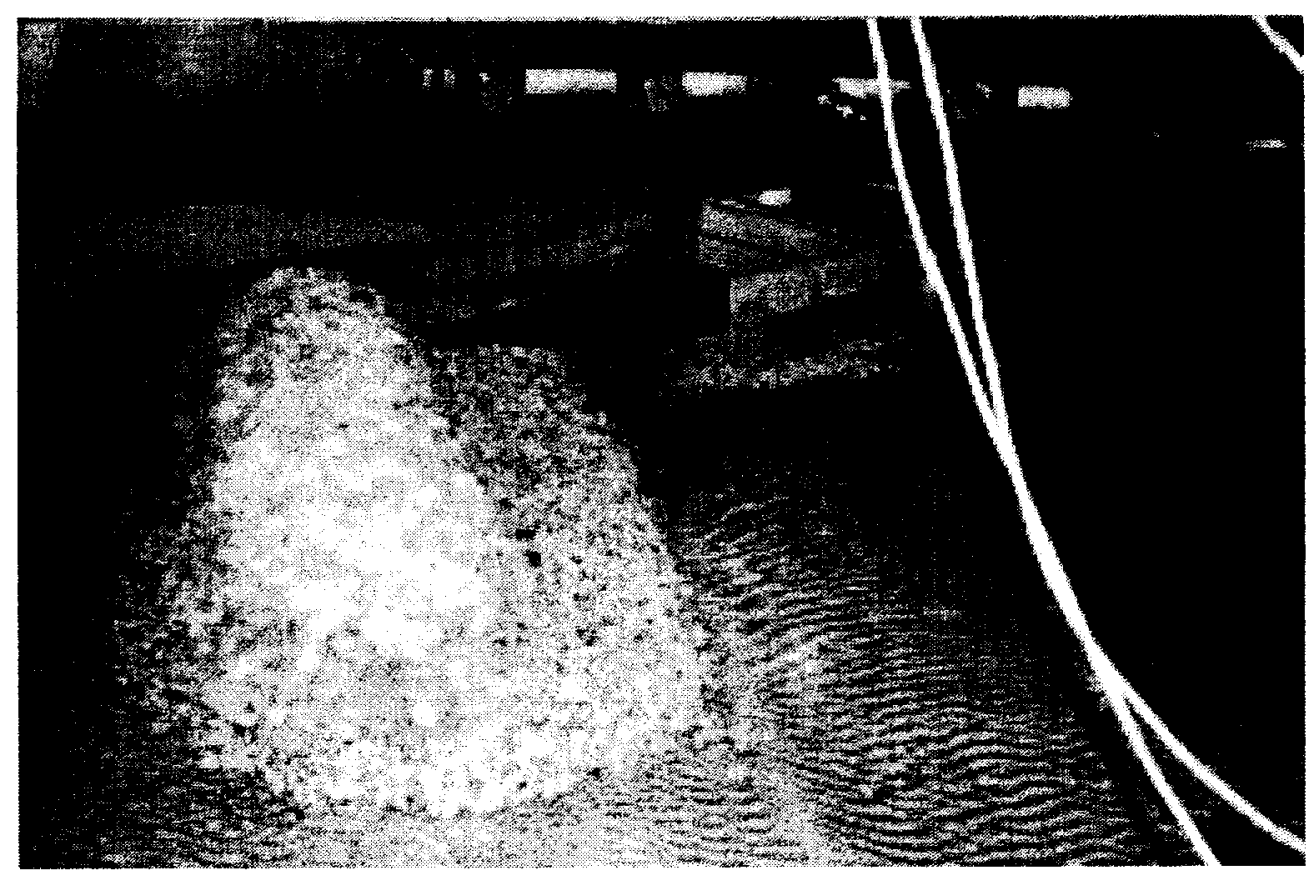

Figure 17. Head-on view of jetty with narrow stone buttress after regular waves

The experiment was initiated on Plan BW-1, using only ebb flow of $0.40 \mathrm{~m} / \mathrm{s}(1.3 \mathrm{ft} / \mathrm{s})$ for a duration of $10 \mathrm{hr}$. Dye was injected into the current to observe the effect of the weirs on flow (Figure 18b). Flow was observed being deflected away from the breakwater. However, scour occurred along the structure toe (Figure 18c).

Additional weirs were placed between the existing weirs of Plan BW-1 to avoid abrupt flow direction changes and provide a smoother flow transition between weirs (Figure 19a). The modified plan, Plan BW-2, was subjected to $10 \mathrm{hr}$ of $0.40 \mathrm{~m} / \mathrm{s}(1.3 \mathrm{ft} / \mathrm{s})$ ebb flow and $2 \mathrm{hr}$ of irregular waves $\left(T_{p}=2 \mathrm{sec}, H_{d}=0.26 \mathrm{~m}(0.86 \mathrm{ft})\right)$. The added weirs reduced flow at the structure toe; however, localized scour was evident at the breakwater toe (Figures $19 b$ and 19c).

Plan BW-3 consisted of placing additional stone on the ends of the Plan BW-2 weirs near the structure side to increase weir elevation at the breakwater. The added stone was placed to deflect flow along the structure. However, the plan was unsuccessful in preventing scour near the breakwater toe.

Experiments conducted with bendway weirs indicated that they may provide adequate toe protection in a wave and flow environment. However, none of the plans examined in the present study protected the structure toe from scour. Proper guidance on use of bendway weirs in a wave and flow environment would require further research. At present, it is recommended that use of bendway weirs for toe protection of coastal structures be evaluated on a site-specific basis using physical models. 


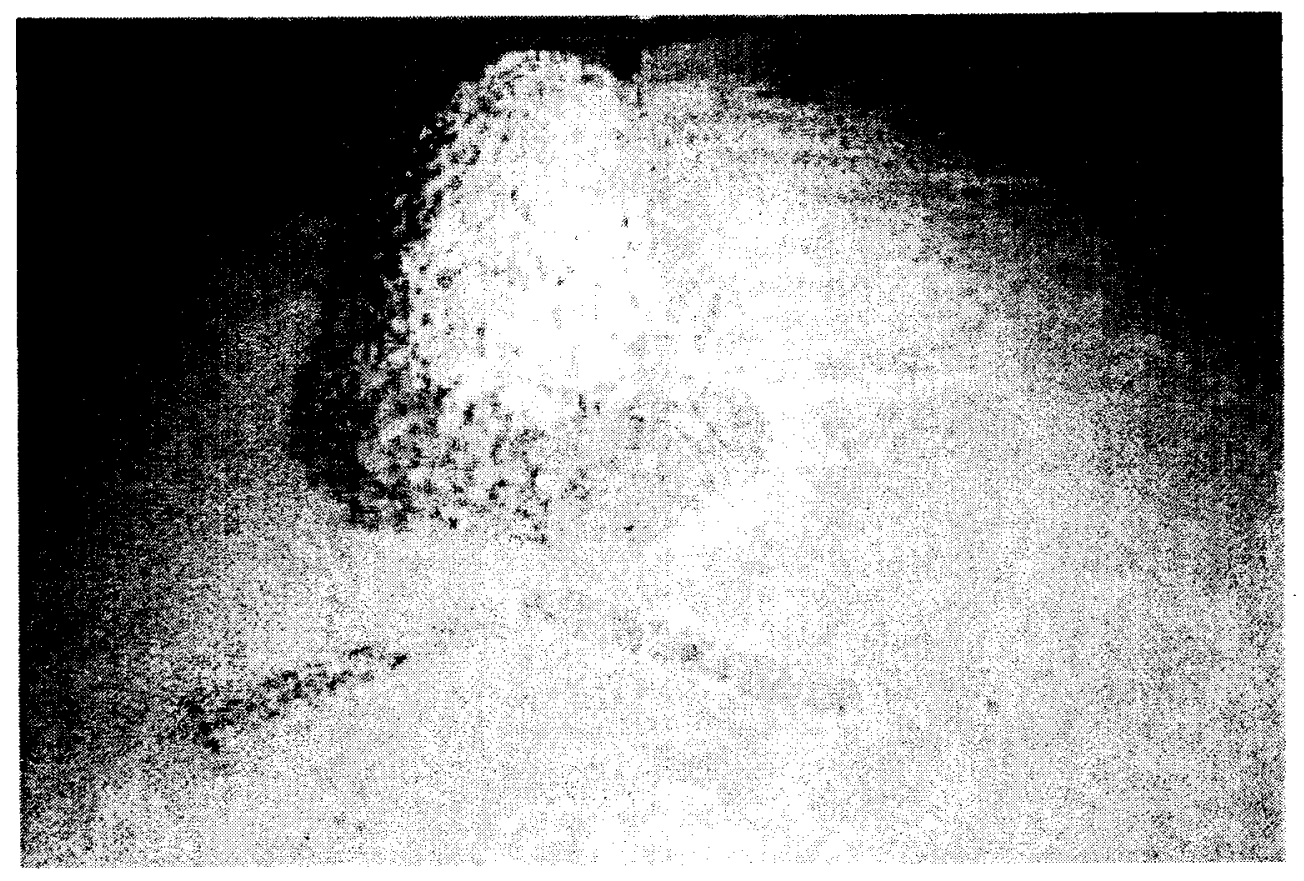

a. Before experiment

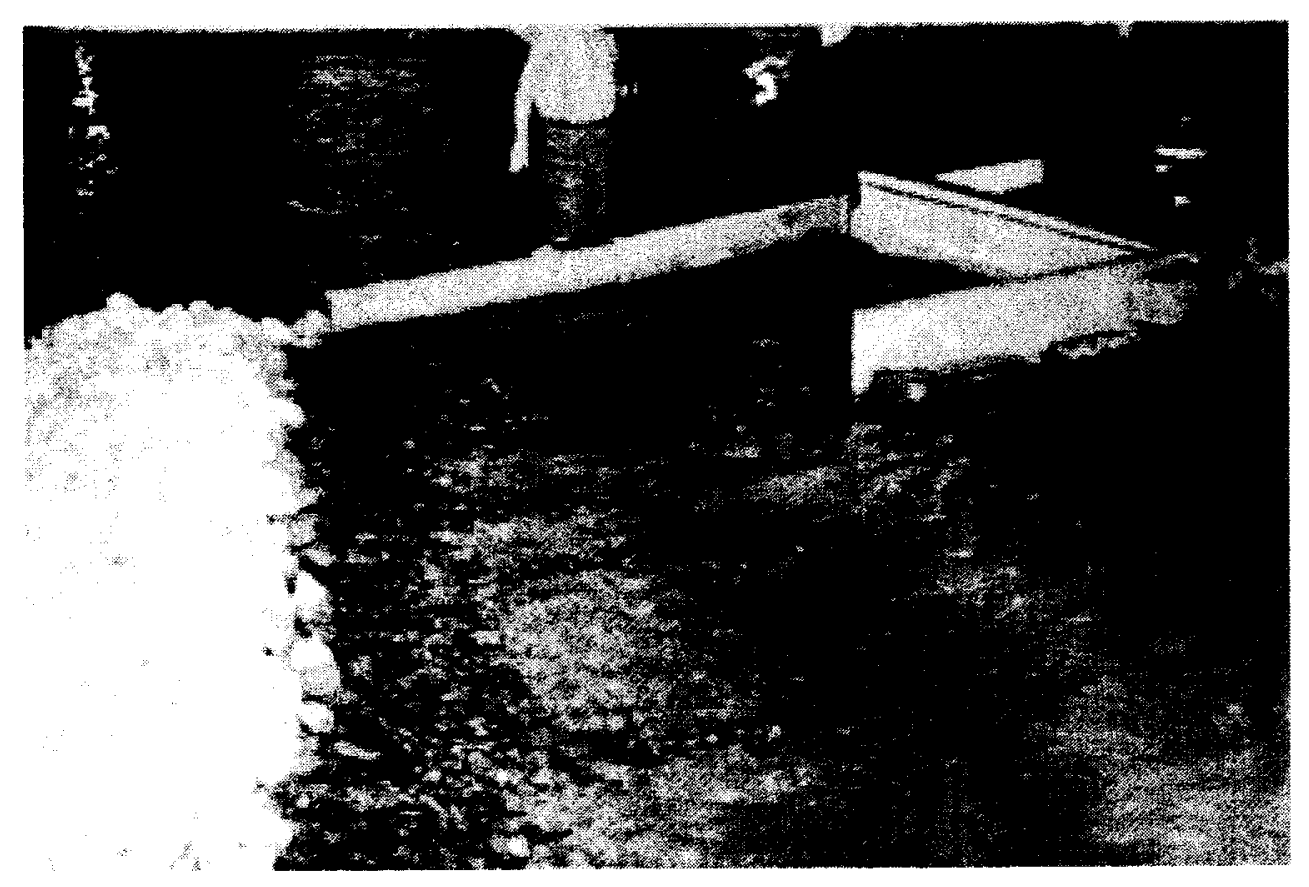

b. During experiment

Figure 18. Views of bendway weir Plan BW-1 (Continued) 


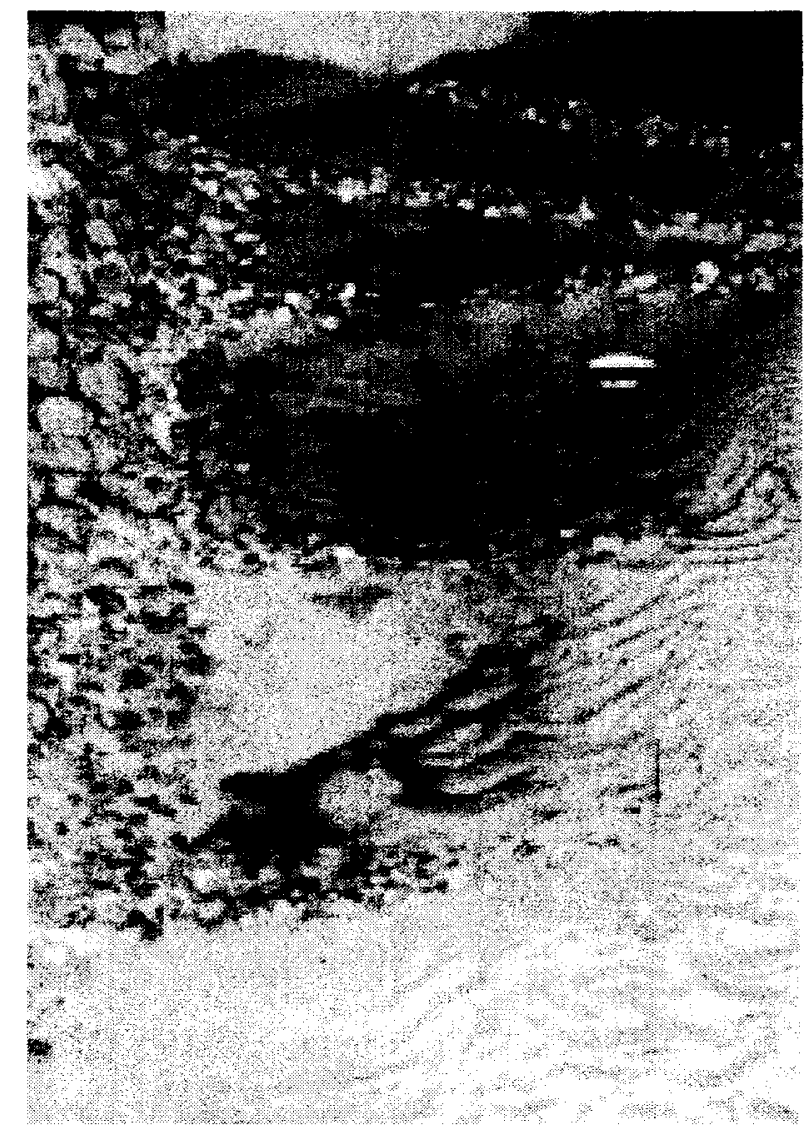

c. After experiment

Figure 18. (Concluded) 


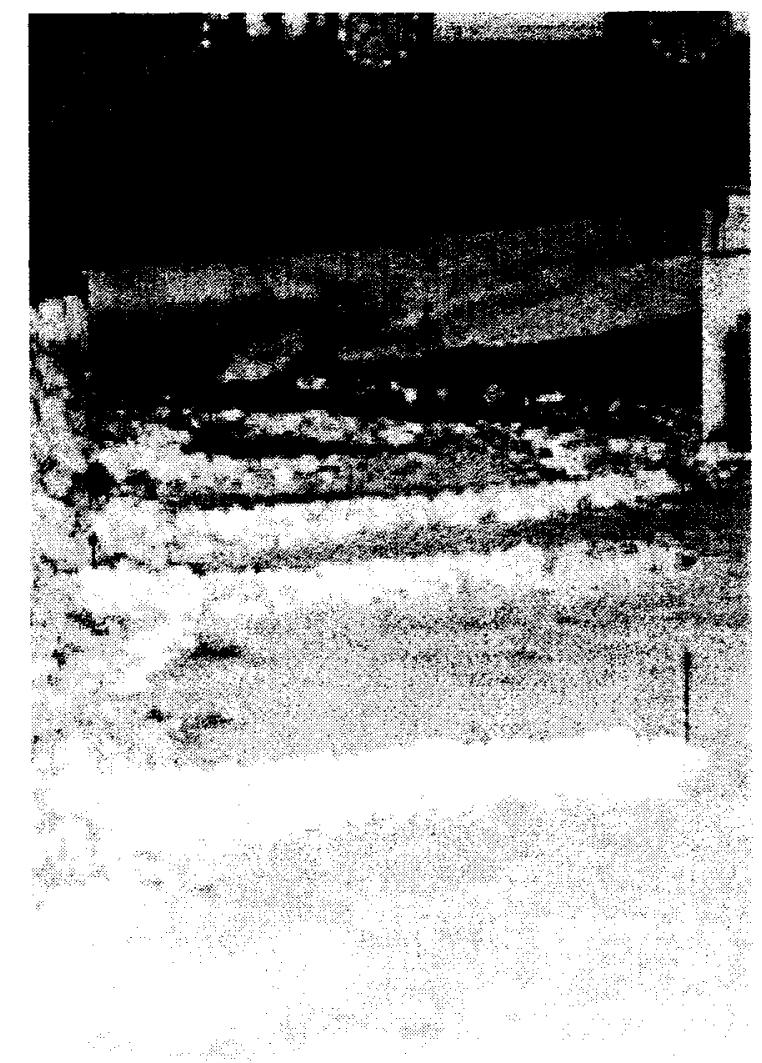

a. Before experiment

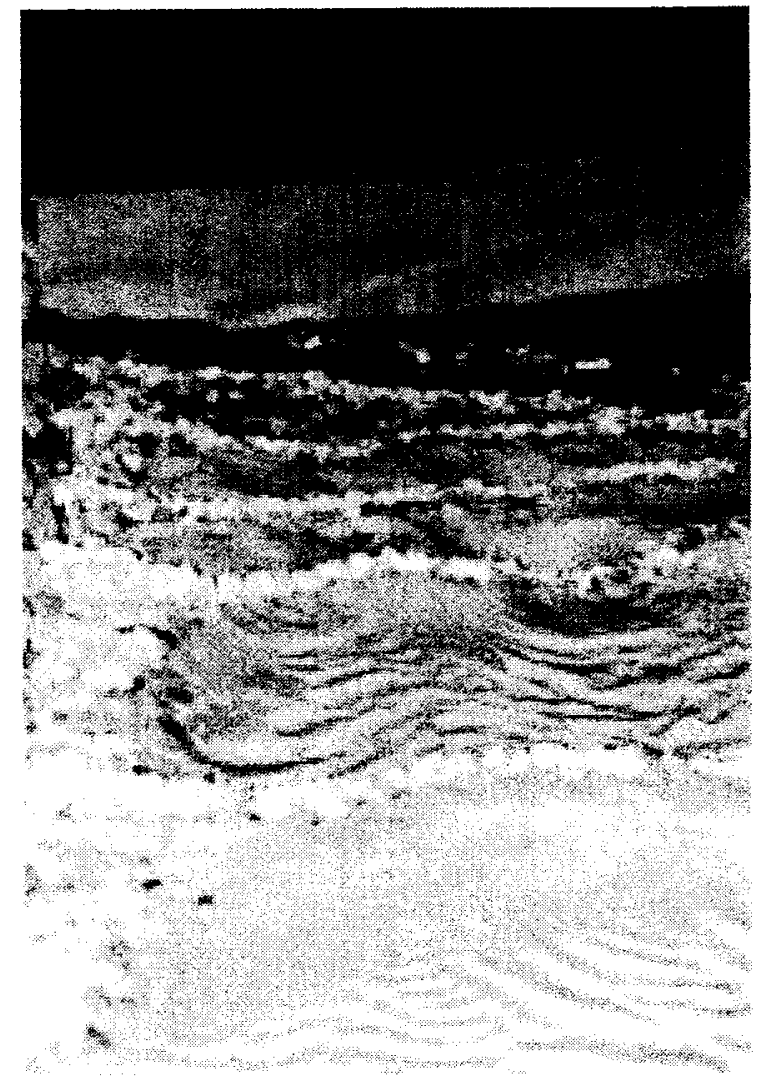

b. After experiment

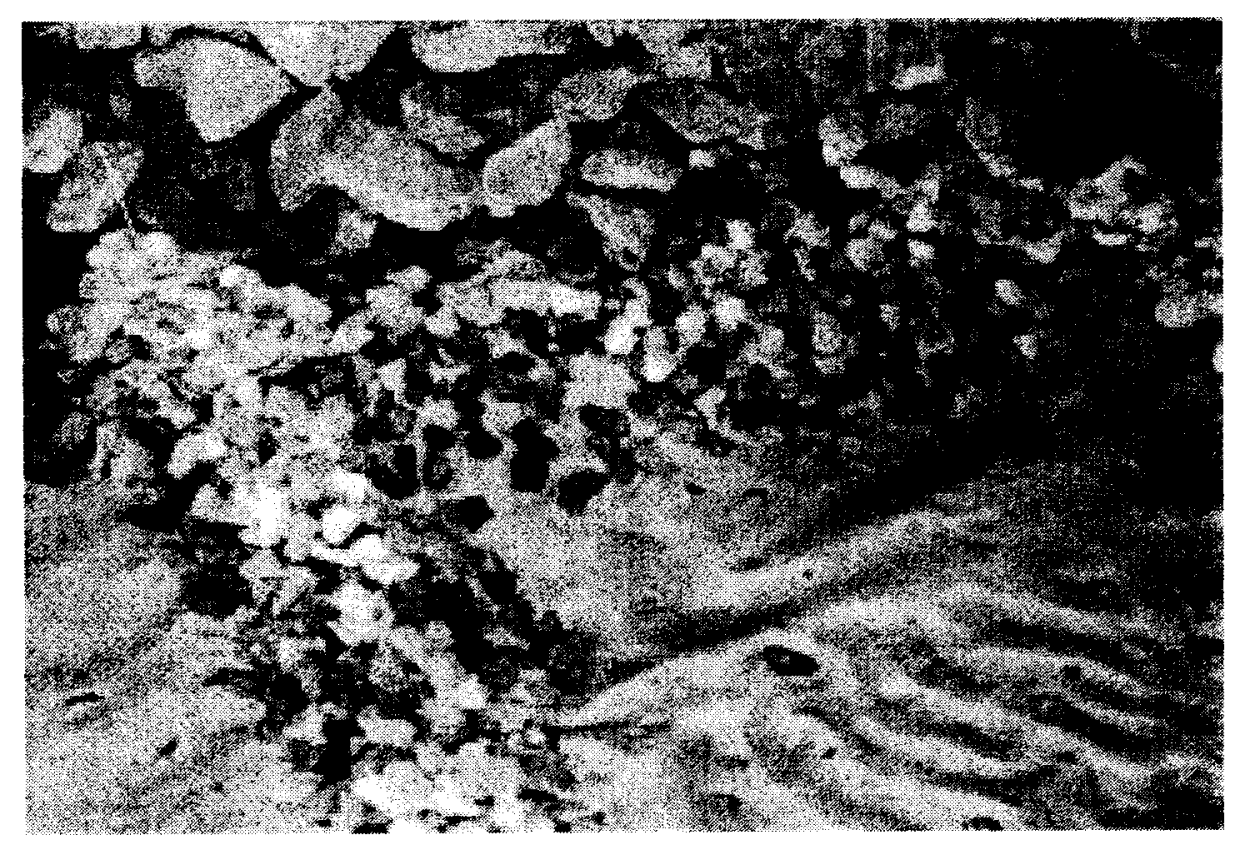

c. Jetty toe after experiment

Figure 19. Views of bendway weir Plan BW-2 


\section{Summary and Conclusions}

A three-dimensional model study was conducted to investigate toe stability of coastal structures in a breaking wave and ebb flow environment. The model study was conducted at a midscale on the order of $1: 25$, model to prototype.

Toe failure generally occurs either by failure of the toe stone due to instability from waves and currents or by undermining of the toe berm or armor by scour of sand. The study consisted of two phases: fixed-bed experiments and movable-bed experiments. The purpose of the fixed-bed experiments was to determine a method to calculate a stable toe stone weight subjected to breaking waves and ebb flow. It was necessary to conduct the experiments on a fixed-bed to isolate the problem and eliminate the variable of scour. Movable-bed experiments were conducted to verify the results of the fixed-bed study.

From the experiments, the following conclusions were derived:

a. Toe stone was less stable if ebb flew was present, and more damage occurred for lower wave heights in the presence of ebb flow than if no flow was present. However, damage did not increase significantly if waves higher than the damaging wave heights were generated because the waves broke farther off shore and dissipated as they reached the structure.

$b$. A pulsating effect was observed at the toe berm for given ebb-flow and wave conditions. This effect occurred as the rundown of waves on the structure and ebb current velocities were in phase. This combination caused a lowering of the water depth over the toe berm, which in turn increased velocities.

c. Based on the fixed-bed experiments, the toe stone weight considering both wave and flow conditions should always be greater than one tenth the primary armor weight presently recommended for acceptable wave stability.

d. Results of the movable-bed experiments verified the method developed during the fixed-bed experiments. The toe stone size calculated from fixed-bed design guidance was stable, and it was 
determined that toe protection should cover at least half the scour hole width.

$e$. The movable-bed experiments conducted with bendway weirs indicated that these structures may be a suitable form of toe protection. However, to develop specific design guidance, additional research would be required. 


\section{References}

Brebner, A., and Donnelly, P. (1962). "Laboratory study of rubble foundations for vertical breakwaters," Civil Engineering Research Report No. 23, Queens University, Kingston, Ontario.

Hughes, S. A. (1984). “The TMA shallow-water spectrum description and applications," Technical Report CERC-84-7, U.S. Army Engineer Waterways Experiment Station, Vicksburg, MS.

Markle, D. G. (1986). "Stability of rubble-mound breakwater and jetty toes; Survey of field experience," Technical Report REMR-CO-1, U.S. Army Engineer Waterways Experiment Station, Vicksburg, MS.

Markle, D. G. (1989). "Stability of toe berm armor stone and toe buttressing stone on rubble-mound breakwaters and jetties; Physical model investigation," Technical Report REMR-CO-12, U.S. Army Engineer Waterways Experiment Station, Vicksburg, MS.

Shore Protection Manual. (1984). 4th ed., 2 vols, U.S. Army Engineer Waterways Experiment Station (available from: U.S. Government Printing Office, Washington, DC).

Tanimoto, K., Yagyu, T., and Goda, Y. (1982). "Irregular wave tests for composite breakwater foundations," Proceedings, Eighteenth Coastal Engineering Conference, ASCE, Vol III, New York, 2144-63. 


\section{Appendix A: Example Problem}

A jetty at an inlet is experiencing toe stability problems. Maximum ebb flows are observed to reach $6.5 \mathrm{ft} / \mathrm{s}$ in the inlet. The design wave condition is an $8-\mathrm{sec}, 15-\mathrm{ft}$ wave. The jetty is constructed of stone on a 1:2 slope at a depth of $20 \mathrm{ft}$. Assume $\gamma_{\mathrm{a}}=165 \mathrm{pcf}, \gamma_{w}=64.0 \mathrm{pcf}$, and $K_{d}$ of the structure is 2. Determine a stable stone size for the toe.

DETERMINE $W_{a}$ :

$$
\begin{aligned}
& W_{a}=\frac{\gamma_{a} H_{d}^{3}}{K_{d}\left(S_{a}-1\right)^{3} \cot \theta} \\
& W_{a}=\frac{165(15)^{3}}{2\left(\frac{165}{64}-1\right)^{3} 2}=35,422 \mathrm{lb}
\end{aligned}
$$

Assume $W_{\text {toe }} \cong 1 / 10 W_{a}=3,500 \mathrm{lb}$. Calculate $N_{s}^{3}$ :

$$
\begin{aligned}
N_{s}^{3} & =\frac{\gamma_{a} H_{d}^{3}}{W_{t o e}\left(S_{a}-1\right)^{3}} \\
& =\frac{165(15)^{3}}{3500\left(\frac{165}{64}-1\right)^{3}}=40
\end{aligned}
$$

Note that $N_{s}^{3}$ is the actual stability number and $\left(N_{s}\right)_{c}^{3}$ must be less than 40 . 
DETERMINE $d_{1} / d_{s}$ :

Assume toe buttress is constructed of quarrystone; use the method given in the Shore Protection Manual (1984) to determine diameter of toe stone, $d_{50}$.

$$
\begin{aligned}
& d_{50}=1.15\left(\frac{W_{t o e}}{\gamma_{a}}\right)^{1 / 3} \\
& d_{50}=1.15\left(\frac{3500}{165}\right)^{1 / 3}=3.2 \mathrm{ft}
\end{aligned}
$$

Calculate $d_{1}$ :

$$
d_{1}=d_{s}-2\left(d_{50}\right)=20-2(3.2)=13.6 \mathrm{ft}
$$

Therefore,

$$
\frac{d_{1}}{d_{s}}=\frac{13.6}{20}=0.68
$$

DETERMINE $a$ from Equation 5:

$$
\begin{aligned}
& a=51.0 \frac{d_{1}}{d_{s}}-26.4 \\
& a=51.0(0.68)-26.4=8.28
\end{aligned}
$$

DETERMINE $u$, maximum horizontal orbital velocity, using Equation 2:

$$
u=\frac{g T H_{d}}{2 L}
$$

First, calculate wave length, $L$

$$
L=g T^{2} \tanh \left(\frac{2 \pi d_{s}}{L}\right)
$$

The equation to determine $L$ requires an iterative solution. Table C1 in the Shore Protection Manual (1984) may also be used. 
For an $8-\mathrm{sec}$ period, $L=190 \mathrm{ft}$ for a depth of $20 \mathrm{ft}$. Therefore, using Equation 4:

$$
u=\frac{(32.2)(8)(15)}{2(190)}=10 \mathrm{ft} / \mathrm{s}
$$

DETERMINE $\left(N_{s}\right)_{c}$ from Equation 4:

$$
\begin{aligned}
& \left(N_{s}\right)_{c}=a\left(\frac{U+u}{\sqrt{g d_{s}}}\right)^{2} \\
& \left(N_{s}\right)_{c}=8.28\left(\frac{6.5+10}{\sqrt{(32.2)(20)}}\right)^{2}=354
\end{aligned}
$$

Thus,

$$
\left(N_{s}\right)_{c}^{3}=(3.54)^{3}=44.2>40
$$

A heavier stone size is required to provide adequate toe protection because $\left(N_{s}\right)_{c}^{3}$ is greater than $N_{s}^{3}$. Through iteration, the minimum stone size required for the example problem is approximately $4,000 \mathrm{lb}$.

To help illustrate this method, calculated stability numbers for the wave and current condition used in the example are shown in Figure A1 for a range of relative depths. The solid line represents the minimum stability curve obtained by cubing the resulting $\left(N_{s}\right)_{c}$ values from Equation 4 over the range of relative depths. All points above this curve represent toe stone weights that should provide a stable toe for the given conditions. If flow is not considered, the resulting minimum stability line for the given wave condition is represented as the dashed line. The dotted line indicates that if no flow were present, all stone sizes with relative depths between 0.58 and 0.80 would be stable, and the initial assumption of $1 / 10 W_{a}$ would provide adequate toe protection.

Another solution to the problem is to excavate sediment at the toe and entrench the armor layer at the toe and the toe buttress. This method allows stone size selection, and the above equations are used to solve for $d_{1} / d_{s}$ to determine the necessary depth of entrenchment. 


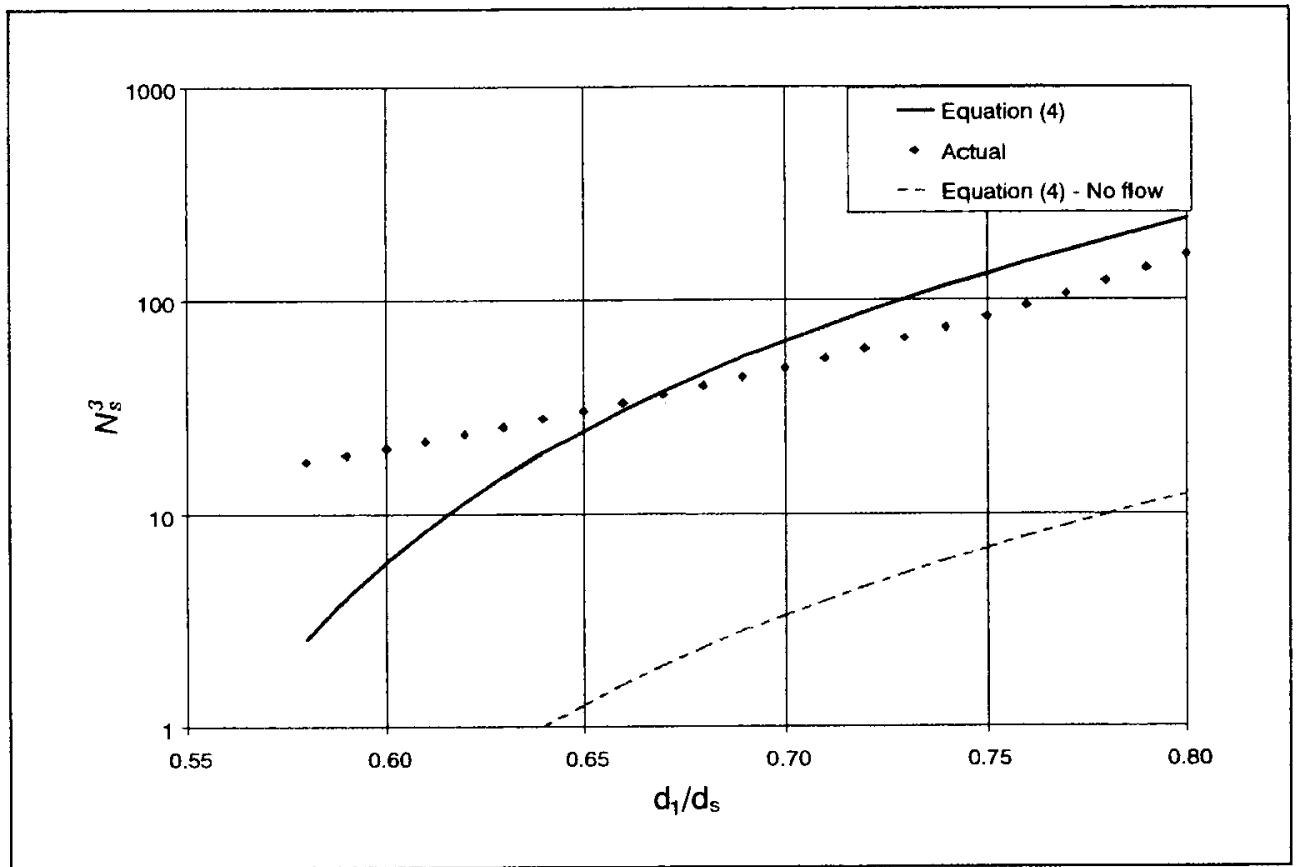

Figure A1. Actual and calculated stability numbers as a function of relative depth 
Public reporting burden for this collection of information is estimated to average 1 hour per response, including the time for reviewing instructions, searching existing data sources, gathering and maintaining the data needed, and completing and reviewing the collection of information. Send comments regarding this burden estimate or any other aspect of this collection of intormation, including sugestions tor reducing this burden, to Washington Headquarters Services, Directorate for Information Operations and Reports, 1215 Jefferson Davis Highway, Suite 1204, Arlington, VA 22202-4302, and to the Office of Management and Budget, Paperwork Reduction Project (0704-0188), Washington, DC 20503.

\begin{tabular}{|l|l|l|}
\hline 1. AGENCY USE ONLY (Leave blank) & $\begin{array}{l}\text { 2. AEPORT DATE } \\
\text { July } 1999\end{array}$ & $\begin{array}{l}\text { 3. AEPORT TYPE AND DATES COVERED } \\
\text { Final report }\end{array}$ \\
\hline
\end{tabular}

4. TITLE AND SUBTITLE

5. FUNDING NUMBERS

Toe Stability of Rubble-Mound Structures in a Breaking Wave and Ebb Flow Environment

6. AUTHOR(S)

Ernest R. Smith

7. PERForming ORGANIZATION NAME(S) AND ADdRESS(ES)

8. PERFORMING ORGANIZATION U.S. Army Engineer Waterways Experiment Station 3909 Halls Ferry Road, Vicksburg, MS 39180-6199 REPORT NUMBER

Technical Report

REMR-CO-20

9. SPONSORING/MONITORING AGENCY NAME(S) AND ADDRESS(ES)

10. SPONSORING/MONITORING U.S. Army Corps of Engineers AGENCY REPORT NUMBER

Washington, DC 20314-1000

11. SUPPLEMENTARY NOTES

Available from National Technical Information Service, 5285 Port Royal Road, Springfield, VA 22161.

12a. DISTRIBUTION/AVAILABILITY STATEMENT

12b. DISTRIBUTION CODE

Approved for public release; distribution is unlimited.

\section{ABSTRACT (Maximum 200 words)}

A three-dimensional physical model study was conducted to investigate toe stability of coastal structures in a breaking wave and ebb flow environment. The model study was conducted at a midscale on the order of 1:25, model to prototype.

The study included both fixed-bed and movable-bed experiments. The purpose of the fixed-bed experiments was to determine a method to calculate a stable toe stone weight subjected to breaking waves and ebb flow. It was necessary to conduct the experiments on a fixed bed to isolate the problem and eliminate the variable of scour. Movable-bed experiments were conducted to verify the results of the fixed-bed study.

A method to determine toe stone size was developed based on fixed-bed experiments using varying values of wave height, wave period, ebb flow velocity, toe stone size, and water depth. The resulting recommendation is that, considering both wave and flow conditions, the toe stone weight required may be greater than one tenth the primary armor weight presently recommended for acceptable wave stability.

(Continued)

\begin{tabular}{|c|c|c|c|c|c|}
\hline \multirow[t]{4}{*}{14.} & \multicolumn{3}{|l|}{ SUBJECT TERMS } & & \\
\hline & Apron stone & Toe $p$ & rotection & & \\
\hline & Rubble toe & Toe $\mathrm{s}$ & cour & & \\
\hline & Toe berm & Toe s & tability & & \\
\hline 17. & $\begin{array}{l}\text { SECURTY CLASSIFICATION } \\
\text { OF REPORT }\end{array}$ & & $\begin{array}{l}\text { SECURITY CLASSIFICATION } \\
\text { OF THIS PAGE }\end{array}$ & & $\begin{array}{l}\text { SECURITY CLASSIFICATION } \\
\text { OF ABSTRACT }\end{array}$ \\
\hline & UNCLASSIFIED & & UNCLASSIFIED & & \\
\hline
\end{tabular}

NSN 7540-01-280-5500

15. NUMBER OF PAGES

41

16. PRICE CODE

20. LIMITATION OF ABSTRACT

Form 298 (Rev. 2 89 )

Prescribed by ANSI Std. Z39-18 298-102 
13. (Concluded).

The movable-bed experiments indicated that toe stone size selected using this method was stable for combined wave and current conditions. Results also indicated that toe protection should cover at least half the scour hole width.

Movable-bed experiments conducted with bendway weirs indicated that these structures may be a suitable form of toe protection. However, development of specific design guidance would require additional research. 